\title{
Biofilm Applications of Bacteriophages
}

\author{
Catarina Milho, Maria Daniela Silva, Sanna Sillankorva, and \\ D. R. Harper
}

\section{Contents}

Applications of Bacteriophages to Biofilms and Surface-Attached Bacteria ............ 2

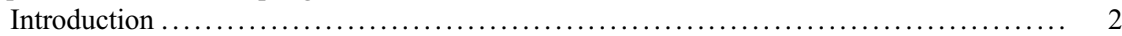

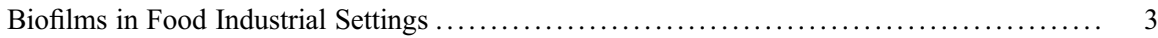

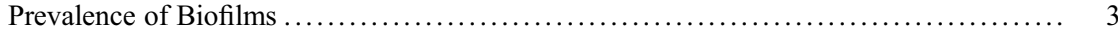

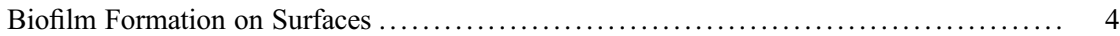

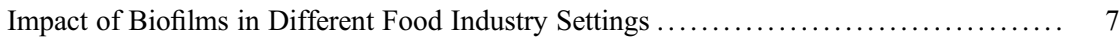

Currently Used Removal Strategies $\ldots \ldots \ldots \ldots \ldots \ldots \ldots \ldots \ldots \ldots \ldots \ldots \ldots \ldots \ldots \ldots \ldots$

Bacteriophage Application to Biofilms and Other Surface-Attached Bacteria

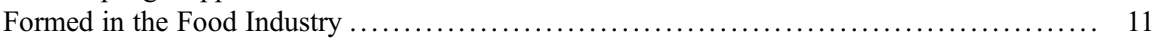

Application of Bacteriophages to Equipment Surfaces and to Working Surfaces and

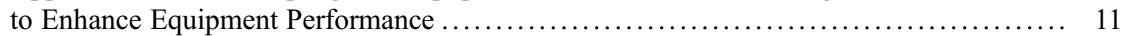

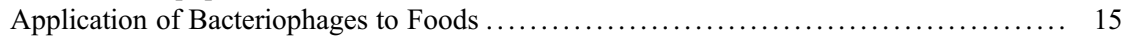

Single Bacteriophage Versus Cocktail Approach and Other Approaches ................ 21

Challenges that Bacteriophages Face in Industrial Environments .................... 22

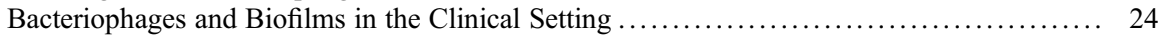

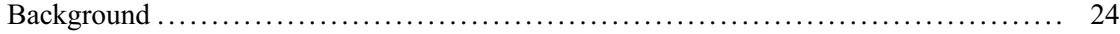

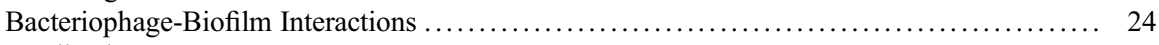

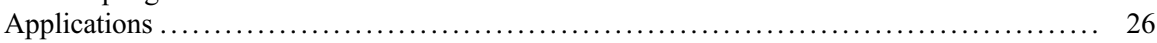

C. Milho · M. D. Silva

CEB - Centre of Biological Engineering, LIBRO - Laboratório de Investigação em Biofilmes Rosário Oliveira, University of Minho, Braga, Portugal

e-mail: catarinamilho@ceb.uminho.pt; mdanielasilva@ceb.uminho.pt

S. Sillankorva $(\bowtie)$

CEB - Centre of Biological Engineering, LIBRO - Laboratório de Investigação em Biofilmes Rosário Oliveira, University of Minho, Braga, Portugal

INL International Iberian Nanotechnology Laboratory Av. Mestre José Veiga s/n4715-330, Braga, Portugal

e-mail: s.sillankorva@deb.uminho.pt

D. R. Harper

Evolution Biotechnologies, Sharnbrook, UK 


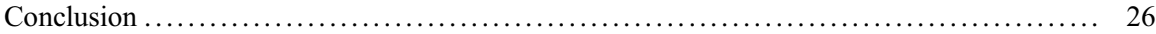

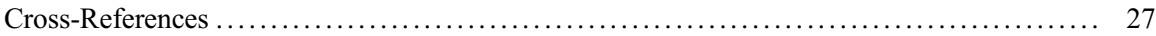

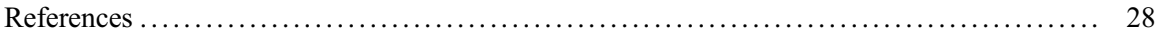

\section{Abstract}

Industrial settings, the food processing industry in particular, have strict sanitation procedures to minimize food product contamination and guarantee that their products are safe to be consumed. Sanitation procedures are routinely used, yet still pathogens are recovered from foods and processing surfaces that may eventually cause foodborne illnesses. Microorganisms have a natural tendency to attach to surfaces - such as food contact surfaces, foods of animal and plant origin, and tubing and equipment, among others - and start forming biofilms, that is, cells are found embedded within a matrix of extracellular polymeric substances.

In this chapter we review fundamental aspects involved in cell adhesion and consequent biofilm formation in food industrial settings and their control and prevention using bacteriophages. The challenges involved in the use of bacteriophages for these applications will also be covered herein.

\section{Applications of Bacteriophages to Biofilms and Surface-Attached Bacteria}

\section{Introduction}

The food industry faces a variety of challenges to keep products safe and free of pathogenic microorganisms, both for the sake of consumers and for the product itself. Nonetheless, there are numerous reports of illness, hospitalization, and even death every year due to a variety of foodborne pathogens present in or on the food we eat. More than 200 different foodborne pathogens - including viruses, bacteria, and parasites - are known to cause foodborne illness, along with toxins, chemical contaminants, and metals. Foodborne outbreaks are linked to intake of contaminated food products such as undercooked meats, fresh vegetables and fruits, ready-to-eat (RTE) foods, etc. Consumer demands and trends in the food industry have led to an increase of the RTE food market section which includes bagged salads, fresh-cut fruits, prepared foods, prepackaged cookie dough, and frozen dishes, among others, that have greatly challenged food production technologies and their associated safety procedures. When food safety measures are not strictly used, then the mixing and handling of enormous volumes of products can increase the spread of microbial contaminants, when present, leading to increased episodes of illness. Many fresh-cut produce products, acquired in markets, are processed in industrial facilities where cross-contamination with pathogenic bacteria from different sources can occur. Food product contamination by bacteria is most likely to occur on the producing farm, at the food processing step (usually resulting from the carcass coming into contact with 
the feces of infected animals during processing) (Morgan et al. 1987), or even with the end user due to cross-contamination events (e.g., poor sanitation practices) (Lynch et al. 2009).

In food industries, pathogenic and spoilage bacteria are consistently found living in sessile communities attached to a wide range of biotic and abiotic surfaces. These communities, better known as biofilms, are accountable for spoilage of products in food, dairy, and food processing industries and can cause transmission of diseases. Biofilms tolerate 100- to 1000-fold higher levels of antimicrobial agents than planktonic cultures, and, although several strategies are adopted to prevent their formation and removal, biofilms do persist in a wide range of industrial surfaces, particularly in hard-to-access zones which are not reached, for instance, by disinfectant agents.

The use and research on the field of natural antimicrobial agents has increased, not only due to concerns with antimicrobial resistance but also due to alterations in consumer positions toward the use of antibiotics and synthetic preservative agents in food, surface detergents, and disinfectants. Bacteriophages have great potential to be used as alternative disinfection and sanitizing agents in different industrial settings, although their application has been studied in a limited range of scenarios. Since the presence of bacterial biofilms in the industrial environment can lead to great monetary losses, due to their potential to give rise to contamination but also because they can literally clog up processes, their eradication is imperative, and the development of new disinfection products such as bacteriophage-based products therefore mandatory. In this way, it is necessary that more studies using bacteriophages for the removal of biofilms from different industrial settings be implemented to assess their potential to control those bacteria which are attached to surfaces rather than solely their free-floating counterparts.

\section{Biofilms in Food Industrial Settings}

\section{Prevalence of Biofilms}

Biofilms in industrial environments are a serious problem, since they may impair the performance of the equipment or even degrade it (Sampathkumar et al. 2005) and can serve as reservoirs of pathogenic and spoilage bacteria, such as Campylobacter, Salmonella, Listeria, Escherichia coli O157:H7, and others, which may contaminate food products. The presence of bacteria in foods results in a reduced shelf life of the food product and subsequent economic loss for the industry (Winkelströter et al. 2014; Coughlan et al. 2016). For long, the economic impact on food contamination due to microbial contamination has led to the loss of tons of foods produced each year (National Research Council (US) Subcommittee on Microbiological Criteria 1985). According to a survey of 2011 of three dozen international companies, 18 percent of these were hit by a food recall that resulted in between $\$ 30$ million and $\$ 99$ million in lost sales, and further 5\% reported an impact of $\$ 100$ million or 
Fig. 1 Biofilm formation in food industry surfaces

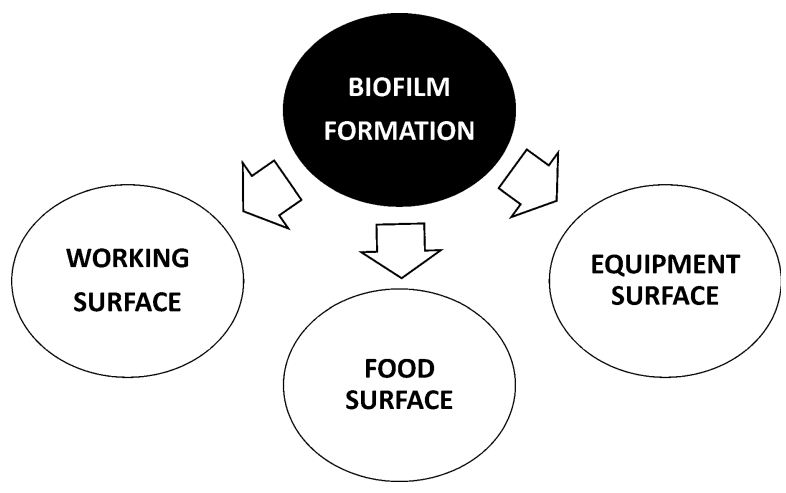

more (Kowitt 2016). These losses are sizeable and can occur already in the production stage, storage, transport and processing, or even with the end consumer.

Notwithstanding the implementation of Hazard Analysis and Critical Control Points (HACCP) in food companies to reduce the amount of contaminated food reaching the consumer, and reducing the incidence of foodborne illnesses, in industrialized countries the number of people who become infected with foodborne diseases is alarming. For instance, the European and US authorities responsible for monitoring and analyzing foodborne diseases reported the following numbers: in 2015 a total of 4362 foodborne outbreaks were identified in Europe; and an estimated 50 million cases of foodborne diseases occur in the USA each year (European Food Safety Authority 2016; Centers for Disease Control and Prevention 2011). In the USA alone, these foodborne zoonotic infections result in 128,000 hospitalizations and 3000 deaths (Centers for Disease Control and Prevention 2011).

In food industrial settings, biofilms may be formed in different types of surface (Fig. 1). Food surfaces and all working surfaces in which foods are processed provide an excellent niche for biofilm formation due to the nutritional richness allied to the suitable conditions of temperature and $\mathrm{pH}$ in the environment (Chmielewski and Frank 2003). Biofilms can also be formed on equipment surfaces, particularly those with high humidity or moisture levels, which do not necessarily contact directly with foods. Cross-contamination, however, is a major cause of food product contamination, for instance, as a result of spread of moisture drops and aerosols formed during cleaning and worker's activity (Sampathkumar et al. 2005).

\section{Biofilm Formation on Surfaces}

There is consensus that biofilm formation involves a series of sequential steps or stages (Fig. 2). First, a conditioning film is formed on a surface. In food environments, organic and inorganic molecules, including proteins, lipids, nucleic acids, and others, released from foods (such as, milk, meat, fruits, vegetables) adsorb to the surface almost immediately after surfaces come into contact with a liquid phase, forming a layer at the water/solid interface. This results in an increased concentration 


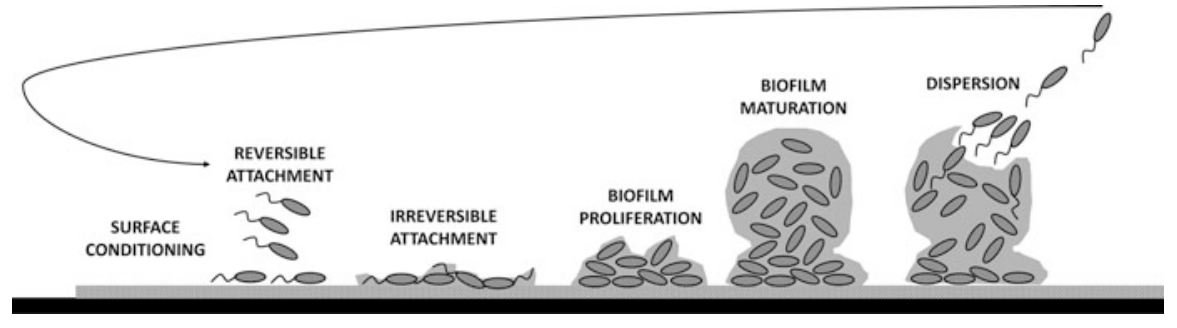

Fig. 2 Biofilm formation steps

of nutrients on the surface and also the alteration of the physicochemical properties of the surface (Kumar and Anand 1998; Korber et al. 2009; Srivastava and Bhargava 2016).

The second stage of biofilm formation is the reversible attachment of bacteria to the surface. Bacteria approach the surface either randomly or in a directed manner via chemotaxis and motility, and weak interactions (such as electrostatic forces, van der Waals forces, hydrophobic interactions) develop between them and the surface. Determination of whether further levels of attachment will occur depends on the net sum of the attractive and repulsive forces that are generated. The physicochemical properties of the surface, the existence of nutrients, the conditions of surrounding environment, the bacterial growth stage, and the existence of bacterial structures, such as fimbriae and flagella, also influence bacterial attachment. It is noteworthy that, in this stage, bacteria can easily be detached from the surface if the environment is not favorable (Kumar and Anand 1998; Dunne 2002; Sampathkumar et al. 2005).

Once reversibly attached, if conditions are favorable, then bacteria can become irreversibly attached. In this stage, several short-range forces are involved, such as dipole-dipole interactions, hydrogen, ionic and covalent bonding, and hydrophobic interactions. The attachment is reinforced by bacterial surface structures, including receptor-specific ligands located on pili, fimbriae, and fibrillae. The most important characteristic of the irreversible attachment stage is the production of extracellular polymeric substances (EPS), which aid in attaching the bacterial cell to the surface. EPS consists mainly of polysaccharides, but it also can contain nucleic and amino acids, glycoproteins and phosphoproteins, sugars, phospholipids, uronic acids, and phenolic compounds. In addition to strengthening the attachment, EPS is responsible for a reduction in diffusional transport (which alters the physiological status of the embedded bacterial cells, decreasing their growth and metabolism rates), nutrient storage, and increased resistance to antimicrobial agents. At the end of this stage, bacterial attachment to the surface is irreversible, unless any physical or chemical intervention is applied (Dunne 2002; Sampathkumar et al. 2005).

Following attachment, bacterial cells grow and divide, intercommunicating through chemical signals. The production of EPS is enhanced, with bacteria multiplying within this structure, which results in the formation of microcolonies. Their continuous growth leads to the formation of a layer of bacterial cells that can cover the entire exposed surface (Kumar and Anand 1998; Prakash et al. 2003). 
The density and complexity of biofilms increases with the continued attachment and growth of bacteria as well as EPS production, resulting in multilayers of bacterial cells embedded within the EPS matrix. Within the biofilm, there also exist water-filled channels that are responsible for transporting nutrients and removing waste products. Different microorganisms with different nutritional requirements can attach and colonize the surface, contributing to the heterogeneity of the biofilm. At this stage, a mature biofilm with a complex three-dimensional structure has formed (Fig. 3) (Kumar and Anand 1998; Prakash et al. 2003).

As biofilms mature, cells detach and disperse from the biofilm. Detachment can be a consequence of nutrient depletion, decreased $\mathrm{pH}$ or oxygenation, and accumulation of toxic products. Fluid dynamics and shear effects of the bulk fluid also contribute to the dispersion of biofilm cells. Specific enzymes that degrade the EPS of different microorganisms may be produced, contributing to the detachment of cells from the biofilm. It is thought that biofilm-released cells are phenotypically more similar to planktonic cells than to biofilm cells. The released cells are able to colonize new niches and initiate the formation of new biofilms (Kumar and Anand 1998; Prakash et al. 2003; Srivastava and Bhargava 2016).

Bacterial organization into multispecies communities attached to surfaces is common in the industry, as in any other natural environment. In fact, life in a multispecies biofilm confers ecological advantages, in comparison to planktonic living or even single-species biofilms. Within the EPS matrix, bacteria are protected from environmental damages, host immune defenses (if the pathogens are infecting animals), and, most relevantly here, from antimicrobial agents. Cells can easily intercommunicate within the biofilm structure and horizontally transfer genes. Furthermore, biofilm formation is associated with an alteration in gene expression, being under the control of a gene regulation system known as quorum sensing. The lower growth rate of bacteria when living as a biofilm is also advantageous, contributing to their increased antimicrobial resistance (Coughlan et al. 2016; Gutiérrez et al. 2016). The presence of persister cells, those that are in a state of dormancy (a state in which cells are metabolically inactive), in the biofilm

Fig. 3 Representation of a mature biofilm

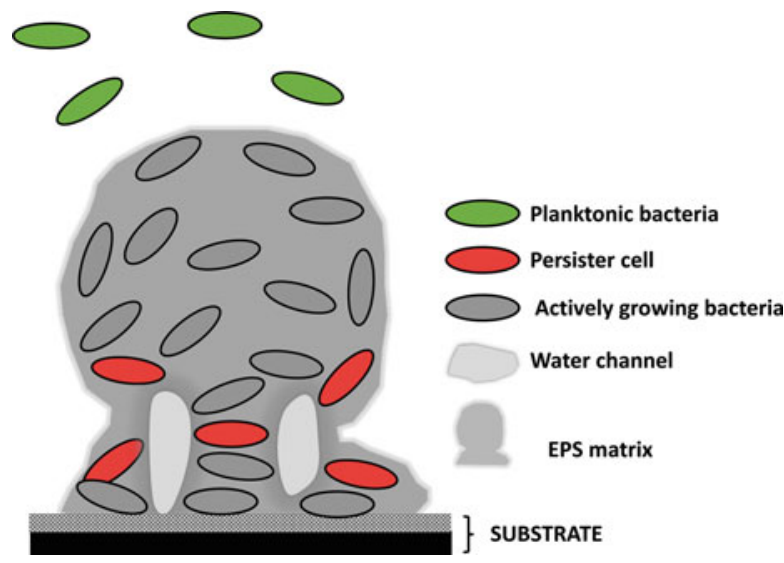


environment is of utmost importance due to their high tolerance to antimicrobials. It has been suggested that persisters are the major element responsible for the recalcitrance of biofilms to these agents (Lewis 2010; Wood et al. 2013).

\section{Impact of Biofilms in Different Food Industry Settings}

Biofilm formation has a notable impact in different food industry settings. Formation of biofilms is of special concern in the dairy, poultry, red meat, seafood, fresh fruits, and vegetable processing industries (Fig. 4). Different approaches have been adopted in order to eliminate biofilms from food environments, including the use of chemical sanitizers (Jahid and Ha 2014), natural compounds (Raffaella et al. 2017), enzymes (Lequette et al. 2010), and others.

\section{Dairy Industry}

In the dairy industry, a wide range of bacterial species with different growth requirements can colonize and form biofilms (Bremer and Seale 2009). Also, milk can become contaminated before entry into the dairy processing plant. Although pasteurization is performed, some bacteria survive this process (Oliver et al. 2005). This is especially the case for thermoduric and thermophilic bacteria, such as sporeforming Bacillus which are of great concern in the dairy industry (Gopal et al. 2015). Furthermore, the manipulation of raw milk can facilitate the spreading of other spoilage and pathogenic bacteria (Bremer and Seale 2009). The deposition of proteins and minerals from milk favors the attachment of some bacteria to food contact

Fig. 4 Fields within the food industry with reported problems due to biofilm formation

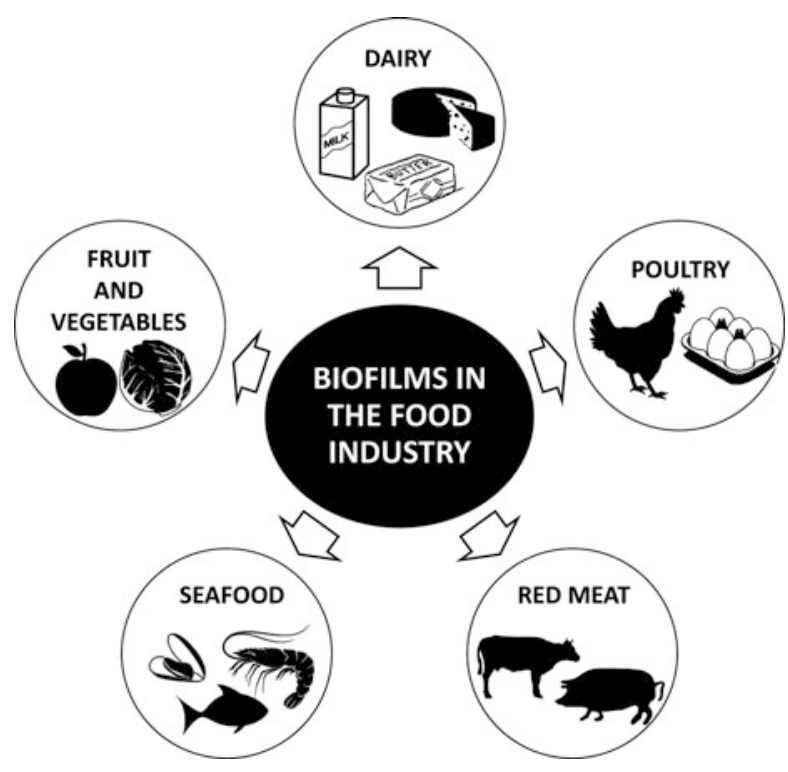


surfaces, which are usually made of stainless steel (Jindal et al. 2016). The different conditions of temperature and $\mathrm{pH}$ favor the formation of biofilms by different bacteria (Gutiérrez et al. 2016). For instance, Listeria monocytogenes is able to grow at cold temperatures, and biofilms formed by this pathogen were reported to be the cause of contamination of bulk tank milk (Latorre et al. 2010). Biofilm formation by thermophilic bacteria, such as Streptococcus thermophilus, is favored in several high-temperature processes of the dairy industry, mainly at plate heat exchangers as used during pasteurization (Bremer and Seale 2009).

\section{Poultry Industry}

Bacteria from poultry carcasses can attach to equipment surfaces and form biofilms, providing a contamination reservoir for the products that pass over the surface of the processing equipment (Arnold 2009). Many poultry products, such as broiler chicken and turkey meats and eggs, are frequently involved in foodborne outbreaks (European Food Safety Authority 2015), and several bacterial species are responsible for these outbreaks. Campylobacter jejuni, for instance, is a common inhabitant of the gastrointestinal tract of poultry and a major cause of food product contamination during processing. Despite its fastidious growth requiring microaerophilic atmosphere and temperatures above $30{ }^{\circ} \mathrm{C}, \mathrm{C}$. jejuni is often found in poultry products, and its presence in multispecies biofilms is thought to be a main reason for C. jejuni's survival in the food industry environment (Teh et al. 2014). Salmonella is another important pathogen frequently isolated from poultry products (Marin et al. 2009) that can easily attach to stainless steel surfaces present in the poultry processing industry and form biofilms even at low temperatures $\left(16^{\circ} \mathrm{C}\right)($ De Oliveira et al. 2014).

\section{Red Meat Industry}

The ability of bacteria to form biofilms is problematic in red meat production and processing industries (Giaouris et al. 2014). Shiga toxin-producing E. coli O157:H7 is an important pathogen related to contamination in this industry (Gutiérrez et al. 2016). This bacterial pathogen forms strong biofilms on stainless steel, and attached cells are easily transferred to food products; in addition, the transferred cells remain strongly attached to food, even after washing (Silagyi et al. 2009). Other studies have reported that E. coli $\mathrm{O} 157: \mathrm{H} 7$ is able to attach and grow as biofilm in bovine meatcontact surfaces not only at the temperature used during non-production hours $\left(15^{\circ} \mathrm{C}\right)$ but also during cold storage temperatures $\left(4^{\circ} \mathrm{C}\right)$, with the latter of special concern (Dourou et al. 2011). Ready-to-eat (RTE) meats are an increasing cause of foodborne outbreaks with deli meats described as the leading cause of listeriosis. Studies have found that $L$. monocytogenes strains involved in the contamination of RTE foods have increased biofilm formation capacity and that cross-contamination from $L$. monocytogenes biofilms present in processing equipment surfaces to RTE meats is the main contamination route (Gibbons et al. 2006; Wang et al. 2015; Møretrø et al. 2017). 


\section{Seafood Industry}

In the seafood industry, several bacterial species can contaminate the processing facilities and form biofilms. Seafood products, including finned fish, crustaceans, mollusks, marine mammals, and fish eggs, can enter the industry already contaminated and cross-contaminate equipment and other food products (Srey et al. 2013; Mizan et al. 2015). The use of seawater instead of freshwater is also a problematic contamination source (Srey et al. 2013). It was reported that even after seawater has been treated, bacteria living as biofilm in the seawater distribution system were not completely eradicated, serving as a bacterial reservoir for the following processes (Shikongo-Nambabi et al. 2010). The most common biofilm-forming pathogens found in the seafood industry are Vibrio cholerae, Vibrio parahaemolyticus, and Vibrio vulnificus. Vibrio spp. are able to form biofilms on different surfaces, such as the chitin of diatoms, oysters, and several other organic and inorganic materials, including stainless steel (Mizan et al. 2016). In addition, other bacteria such as Salmonella spp., L. monocytogenes, and Aeromonas hydrophila are also associated with the formation of biofilms in the seafood industry (Srey et al. 2013; Mizan et al. 2015). A seafood industry study showed that adherent bacteria were found in many locations of seafood processing lines even after cleaning and disinfection procedures (Guobjörnsdóttir et al. 2005). A correlation between the persistence in the fish industry and the ability to form biofilms was demonstrated for different strains of Salmonella (Vestby et al. 2009).

\section{Fresh Fruit and Vegetable Industry}

Fresh fruit and vegetables have the potential to harbor bacterial pathogens, including L. monocytogenes, Salmonella spp., and E. coli O157:H7, which have been increasingly implicated in foodborne outbreaks (Beuchat 2002; Centers for Disease Control and Prevention 2016). Moreover, it was reported that most of bacteria isolated from food and non-food contact surfaces in fresh-cut processing facilities are able to form biofilms, with about $30 \%$ of them being strong or moderate biofilm formers (Liu et al. 2013). Colonization of fruits and vegetables can occur at any stage of preharvest and post-harvest operations. During fresh produce processing, either trimming, cutting, washing, rising, dewatering, or packaging can be a source of crosscontamination. Biofilms formed on the surfaces of fresh produce, such as of leafy greens, apples, and melons, and on equipment surfaces greatly facilitate this process (Annous et al. 2009; Srey et al. 2013).

\section{Currently Used Removal Strategies}

One of the most important features of biofilms is their increased antimicrobial resistance. Microorganisms living as a biofilm can be higher than 1000-fold and more resistant to antimicrobials than their planktonic counterparts. This resistance has been attributed to the reduced diffusion of the antimicrobial due to the presence of EPS, physiological changes caused by the decreased growth rate of cells, and the 
production of enzymes that degrade antimicrobial compounds (Kumar and Anand 1998; Winkelströter et al. 2014).

In this regard, regular cleaning and disinfection procedures are of most importance in the food industry to prevent the irreversible attachment of bacteria to surfaces and the subsequent proliferation of biofilms (Simões et al. 2010). Food debris and other residues should be effectively removed by cleaning, since biofilm formation and the efficacy of disinfectants are, respectively, positively and negatively influenced by their presence (Van Houdt and Michiels 2010). Several chemical products may be used during cleaning depending on the type of soil or dirt. Most of them are surfactants or alkali compounds that decrease the surface tension, emulsify fats, and denature proteins, thus suspending and dissolving food debris (Simões et al. 2010). In some instances, the use of acid cleaners is required for surfaces bearing precipitated minerals or with high levels of food residues/minerals. Nonionic wetting agents are used due to their ability to control foaming and their good emulsifying properties. Depending on water hardness, sequestrants can be used to chelate minerals (Chmielewski and Frank 2003). It is very important that these agents, used during the cleaning process, disrupt or dissolve the EPS matrix in order to allow the access of disinfectants to the viable cells (Simões et al. 2010). The type of chemical agents used, the contact time, the temperature, and the application of mechanical forces are variables that together can greatly influence the efficiency of cleaning (Van Houdt and Michiels 2010). Cleaning procedures can remove most of the microorganisms associated with a surface, but are not necessarily able to kill them. Therefore, removed microorganisms can reattach to other surfaces and initiate the formation of novel biofilms (Simões et al. 2010; Srey et al. 2013).

Antimicrobial agents are used during disinfection procedures, which are often performed after cleaning, with the aim of killing the microorganisms. They are applied as a liquid spray to kill microorganisms on surfaces or, alternatively, as a fine mist to kill airborne microorganisms (Coughlan et al. 2016). The presence of organic substances (fat, carbohydrates, and protein based materials), water hardness, temperature, $\mathrm{pH}$, time of application, and degree of physical contact with the microorganisms are limiting factors for the effectiveness of the antimicrobial agents (Simões et al. 2010; Srey et al. 2013). A wide range of disinfectants are used in the food industry, including chlorine, quaternary ammonium compounds (QAC), hydrogen peroxide, peracetic acid, ozone, phosphoric acid, sulfamic acid, and acid blends (Chmielewski and Frank 2003).

Although cleaning and disinfection procedures can be efficient in removing and then killing bacteria before they irreversibly attach to a surface, elimination of mature biofilms is a more difficult task. Interestingly, the selection of antimicrobial agents to be used tends to be based on studies performed with planktonic cells, though it is common sense that biofilm cells have an increased resistance to their action (Simões et al. 2010; Coughlan et al. 2016). Several studies have reported lower susceptibility of biofilms formed by spoilage and pathogenic bacteria to common disinfectants used in the food industry. For instance, Corcoran et al. assessed the activities of sodium hypochlorite, sodium hydroxide, and benzalkonium chloride against Salmonella enterica biofilms from food contact surface materials, 
and none of the three antimicrobial agents eradicated the biofilms (Corcoran et al. 2014). Other studies also have reported the resistance of Salmonella biofilm cells to disinfectants commonly used in the food industry (Joseph et al. 2001). Pan et al. (2006) used a hydrogen peroxide-based agent against L. monocytogenes biofilms and found that it was ineffective in their elimination. These findings suggest that there is a need of new strategies to control biofilms, particularly in the food industry where biofilms are associated with spoilage food, economic losses, and foodborne illnesses/outbreaks.

Current strategies used to manage foodborne pathogenic bacteria can also be done using physical disruption, including heat, steam, and UV-light irradiation to non-selectively reduce the bacterial loads on food contact surfaces (Stanfield 2003; Delaquis and Bach 2012). Another food processing technique is high hydrostatic pressure (HHP) that works between pressure ranges of 100 and $1200 \mathrm{MPa}$ and has great effectiveness in inactivating microorganisms (Chawla et al. 2011). HHP was first reported to have effect on foodborne microorganisms in 1899 when milk was subjected to $650 \mathrm{MPa}$ for $10 \mathrm{~min}$ at room temperature (Hite 1899).

There are many chemical-, mechanical-, thermal-, and pressure-mediated systems in use, and in addition to being effective, the current products and procedures should be safe, easy to use, and economical. Some of the technologies in use can, however, have significant downsides, such as corrosion of equipment, toxic chemical residues, and damage to the quality of foods. For instance, chlorine-based compounds have to be rinsed off from the surfaces in order to eliminate toxic products that can affect the final properties of the foods (Sampathkumar et al. 2005; Simões et al. 2010).

\section{Bacteriophage Application to Biofilms and Other Surface-Attached Bacteria Formed in the Food Industry}

Bacterial biofilms can grow in virtually any industrial setting, causing damage to working surfaces, equipment, and food products. In this section, we discuss the application of bacteriophages to the different surfaces depicted in Fig. 1 with the main outcomes of these studies detailed in separate subsections.

\section{Application of Bacteriophages to Equipment Surfaces and to Working Surfaces and to Enhance Equipment Performance}

Biofilm formation, which starts with an initial reversible bacterial attachment, may cause several equipment operating troubles, including decreased heat transfer, blocking of tubes, and plugging of filters. Biofilm formation may also be related to damage of surfaces (pitting and corrosion), which most likely leads to further microbial growth on those surfaces. The presence of biofilms on improperly disinfected and sanitized working surfaces (reviewed in Giaouris et al. 2014 and Coughlan et al. 2016) can lead to food product contamination and spoilage, which causes great monetary losses for the food industry and represents a risk to consumer 
health. Therefore, good disinfection procedures must be applied within processing plants, and bacteriophages present themselves as potential disinfection tools since they are effective in the control and eradication of biofilms, are nontoxic to humans, and are also considered to be environmentally sound ("green") (see - "Bacteriophages as Biocontrol Agents"). Table 1 summarizes all bacteriophage work carried out against biofilms that mimic working and equipment surfaces and bacteriophage application to filtration systems to enhance their performance.

Outbreaks linked to consumption of spinach have raised awareness that during harvesting, harvester blades can potentially come into contact with fecal matter (Centers for Disease Control and Prevention 2006). Pathogens in fecal matter or improperly composted manure may attach to the harvester blades and potentiate biofilm formation. To study this, bacteriophages specific for E. coli $\mathrm{O} 157: \mathrm{H} 7$ were used on biofilms formed on spinach harvester blades. The blades were immersed in a cocktail of five bacteriophages (Patel et al. 2011) and after $2 \mathrm{~h}$ reduced bacterial loads on the blades by $4.5 \log _{10}$. The action of bacteriophages against biofilms formed on food working surface materials such as stainless steel, ceramic tile, and glass has been studied (see Fig. 5). For instance, two bacteriophages specific for Pseudomonas fluorescens (phi-S1 and philBB-PF7A) showed good biomass removal efficiencies at optimal conditions (Sillankorva et al. 2004, 2008). Combining phiIBB-PF7A with a bacteriophage specific for Staphylococcus lentus, phiIBBSL58B, significantly decreased dual-species biofilm populations after $2 \mathrm{~h}$ of bacteriophage application (Sillankorva et al. 2010). Furthermore, to test the hypothesis if a single bacteriophage could reach its host and cause destruction in the presence of a non-specific host, the $P$. fluorescens bacteriophage $\Phi I B B-P F 7 A$ was added to dualspecies biofilms. This approach not only reduced viable cell counts but also caused detachment of the non-susceptible host to the planktonic phase. In another study, stainless steel, ceramic tile, and high-density polyethylene chips were artificially contaminated with E. coli $\mathrm{O} 157: \mathrm{H} 7$ and then challenged with a bacteriophage mixture called BEC8 at different multiplicities of infection (MOI) and also at different temperatures (Viazis et al. 2011). At temperatures above $12{ }^{\circ} \mathrm{C}$ and a MOI of 100 , no surviving cells were detected after 10 to 60 min of incubation. Another study using bacteriophages against biofilms formed on food contact surfaces (stainless steel and glass surfaces) was carried out with the bacteriophage cocktail SalmoFresh $^{\mathrm{TM}}$, consisting of six lytic bacteriophages specific for Salmonella. In this experiment, SalmoFresh ${ }^{\mathrm{TM}}$ was capable of significantly reducing the number of Salmonella Kentucky (Salmonella enterica subsp. enterica serovar Kentucky) and S. Brandenburg (Salmonella enterica subsp. enterica serovar Brandenburg) attached to the surfaces (Woolston et al. 2013). The presence of L. monocytogenes biofilms on food working surfaces is also a great concern to the food industry. Hence, many studies have been done with bacteriophages regarding elimination of $L$. monocytogenes biofilm. The effectiveness of three L. monocytogenes specific bacteriophages (LiMN4L, LiMN4p, and LiMN17) was tested individually or as a cocktail against $L$. monocytogenes biofilms grown on stainless steel coupons with or without a fish broth layer (Arachchi et al. 2013). Treatment of both surfaces with single bacteriophages reduced bacterial cells, 
Table 1 Bacteriophage publications against biofilms in working and equipment surfaces

\begin{tabular}{|c|c|c|c|}
\hline \multicolumn{4}{|c|}{ Working and equipment surfaces } \\
\hline Bacteria; surface & $\begin{array}{l}\text { Bacteriophage or } \\
\text { bacteriophage } \\
\text { cocktail }\end{array}$ & $\begin{array}{l}\text { Treatment efficacy (reduction of } \\
\text { viable cells) }\end{array}$ & Reference \\
\hline \multicolumn{4}{|c|}{ Bacteriophage application to control biofilm formation } \\
\hline $\begin{array}{l}\text { P. fluorescens; stainless } \\
\text { steel }\end{array}$ & Phi-S1 & $\begin{array}{l}\text { Biomass reduction of } 85 \% \text { using } \\
\text { MOI of } 0.5\end{array}$ & $\begin{array}{l}\text { Sillankorva } \\
\text { et al. (2004) }\end{array}$ \\
\hline $\begin{array}{l}\text { P. fluorescens; stainless } \\
\text { steel }\end{array}$ & PhilBB-PF7A & $\begin{array}{l}\text { Biomass removal varied between } \\
63 \text { and } 91 \% \text { depending on biofilm } \\
\text { age and infection conditions }\end{array}$ & $\begin{array}{l}\text { Sillankorva } \\
\text { et al. (2008) }\end{array}$ \\
\hline $\begin{array}{l}\text { P. fluorescens and } \\
\text { S. lentus; stainless steel }\end{array}$ & $\begin{array}{l}\text { PhiIBB-PF7A and } \\
\text { philBB-SL58B }\end{array}$ & $\begin{array}{l}\text { Significant reduction after } 2 \mathrm{~h} \text { of } \\
\text { treatment; bacteriophage } \Phi \mathrm{IBB}- \\
\text { PF7A reduced cell counts by } \\
3 \log _{10} \text { in dual species biofilms }\end{array}$ & $\begin{array}{l}\text { Sillankorva } \\
\text { et al. (2010) }\end{array}$ \\
\hline $\begin{array}{l}\text { E. coli } \mathrm{O} 157: \mathrm{H} 7 \\
\text { spinach harvester blades }\end{array}$ & $\begin{array}{l}\text { Cocktail of } \\
5 \text { bacteriophages }\end{array}$ & $\begin{array}{l}\text { Reduction of } 4.5 \log _{10} \text { after } 2 \mathrm{~h} \text { of } \\
\text { incubation }\end{array}$ & $\begin{array}{l}\text { Patel et al. } \\
\text { (2011) }\end{array}$ \\
\hline $\begin{array}{l}\text { E. coli } \mathrm{O} 157: \mathrm{H} 7 \\
\text { stainless steel and } \\
\text { ceramic tile }\end{array}$ & BEC8 cocktail & $\begin{array}{l}\text { No E. coli } \mathrm{O} 157: \mathrm{H} 7 \text { cells detected } \\
\text { after } 10 \text { min of incubation with } \\
\text { MOI of } 100 \text { at } 37^{\circ} \mathrm{C}\end{array}$ & $\begin{array}{l}\text { Viazis et al. } \\
\text { (2011) }\end{array}$ \\
\hline $\begin{array}{l}S . \text { Kentucky and } S \text {. } \\
\text { Brandenburg; stainless } \\
\text { steel and glass }\end{array}$ & $\begin{array}{l}\text { SalmoFresh } \\
\text { cocktail }\end{array}$ & $\begin{array}{l}\text { Decrease on number of cells by } \\
2.1-4.3 \log _{10}\end{array}$ & $\begin{array}{l}\text { Woolston } \\
\text { et al. (2013) }\end{array}$ \\
\hline $\begin{array}{l}\text { L. monocytogenes; } \\
\text { stainless steel coupons } \\
\text { with or without a fish } \\
\text { broth layer }\end{array}$ & $\begin{array}{l}\text { LiMN4L, LiMN4p } \\
\text { and LiMN17 } \\
\text { individually or in } \\
\text { cocktail }\end{array}$ & $\begin{array}{l}\text { On both surfaces, single } \\
\text { bacteriophages reduced cells by } \\
3-4.5 \log _{10} \text {, and cocktail by } \\
3.8-5.4 \log _{10}\end{array}$ & $\begin{array}{l}\text { Arachchi et al. } \\
\text { (2013) }\end{array}$ \\
\hline $\begin{array}{l}\text { V. alginolyticus; } \\
\text { polystyrene }\end{array}$ & VP01 & $\begin{array}{l}\text { Cell counts were reduced by } \\
56 \text { and } 86 \% \text {, when using } \\
\text { bacteriophage concentrations of } \\
10^{10} \text { and } 10^{12}\end{array}$ & $\begin{array}{l}\text { Sasikala and } \\
\text { Srinivasan } \\
\text { (2016) }\end{array}$ \\
\hline $\begin{array}{l}\text { L. monocytogenes; } \\
\text { stainless steel and } \\
\text { polypropylene cylinders }\end{array}$ & $\begin{array}{l}\mathrm{H} 387, \mathrm{H} 387-\mathrm{A}, \\
\text { and 2671in } \\
\text { combination with } \\
\text { QUATAL }\end{array}$ & $\begin{array}{l}\text { The efficiency of combined } \\
\text { agents was higher compared to } \\
\text { their use individually }\end{array}$ & $\begin{array}{l}\text { Roy et al. } \\
\text { (1993) }\end{array}$ \\
\hline $\begin{array}{l}\text { P. aeruginosa; glass } \\
\text { coupons }\end{array}$ & $\begin{array}{l}\text { Cocktail of RNA } \\
\text { bacteriophages } \\
\text { combined with } \\
\text { chlorine }\end{array}$ & $\begin{array}{l}\text { Removal of } 97 \% \text { of } P \text {. aeruginosa } \\
\text { biofilms after combined } \\
\text { treatment. The products alone } \\
\text { reduced biofilm by } 89 \% \text { (cocktail) } \\
\text { and } 40 \% \text { (chlorine) }\end{array}$ & $\begin{array}{l}\text { Zhang and Hu } \\
\text { (2013) }\end{array}$ \\
\hline $\begin{array}{l}\text { P. aeruginosa; water and } \\
\text { wastewater filtration } \\
\text { systems }\end{array}$ & $\begin{array}{l}\text { Cocktail of RNA } \\
\text { bacteriophages }\end{array}$ & $\begin{array}{l}\text { After } 1 \mathrm{~h} \text { dosing on day } \\
136, \text { removal increased by } 56 \% \\
\text { and } 70 \% \text {, in anthracite and } \\
\text { granular activated biofilters }\end{array}$ & $\begin{array}{l}\text { Zhang et al. } \\
\text { (2013) }\end{array}$ \\
\hline $\begin{array}{l}\text { D. tsuruhatensis; } \\
\text { wastewater filtration } \\
\text { system }\end{array}$ & DTP1 & $\begin{array}{l}\text { Treatment increased the flux by } \\
70 \% \text { of the original }\end{array}$ & $\begin{array}{l}\text { Bhattacharjee } \\
\text { et al. (2015) }\end{array}$ \\
\hline
\end{tabular}

though the use of the bacteriophage cocktail led to higher reductions on both surfaces. Steel present in food production facilities can support reservoirs of pathogenic bacteria. Listex ${ }^{\mathrm{TM}}$ P100 bacteriophage was used in the control of 

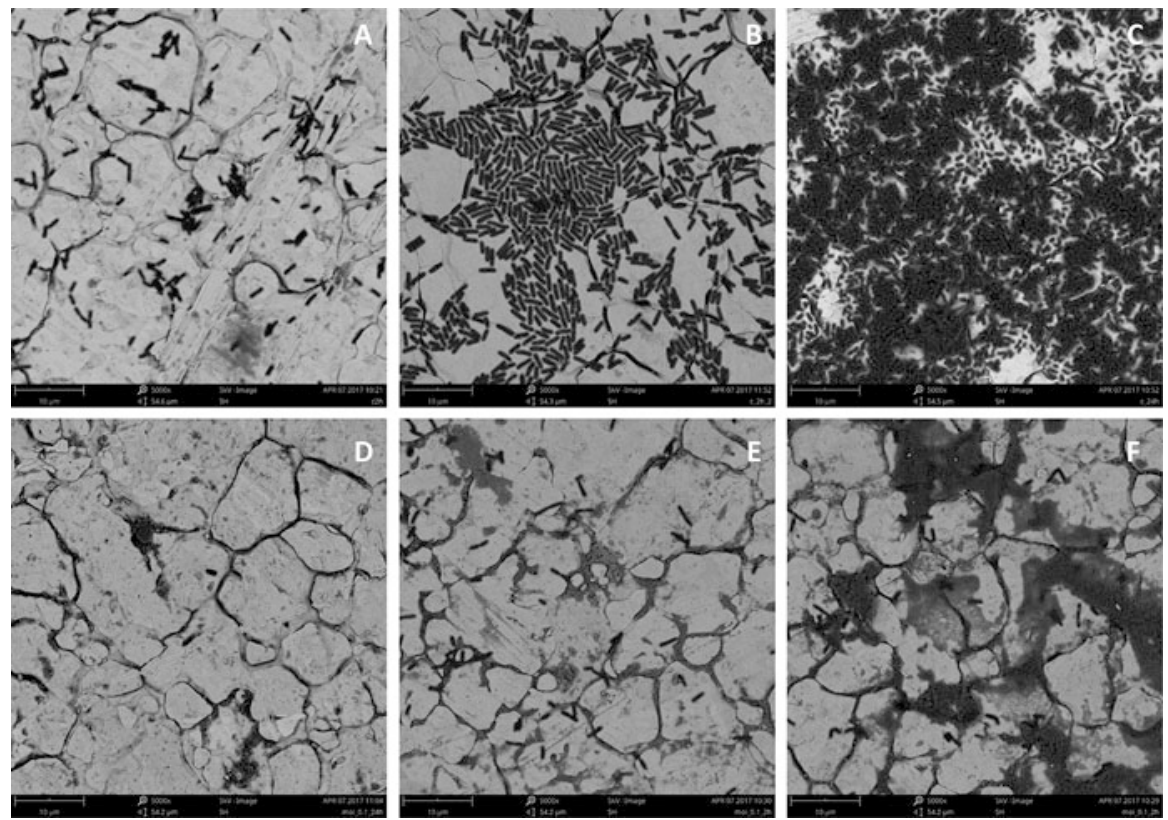

Fig. $5 S$. Enteritidis adhesion and biofilm formation on stainless steel (a-c) and treatment with bacteriophage phi38 (unpublished data). (a) Cell adhesion, (b) proliferation, (c) microcolonies, and (d-f) biofilms treated with bacteriophage phi38 at a multiplicity of infection of 1; some cells are still present but mainly the surface is covered with cell debris

L. monocytogenes biofilms formed on steel wafers, and the end result was complete elimination of the biofilms from these surfaces (Iacumin et al. 2016). L. monocytogenes bacteriophages have also been tested in combination with QUATAL (10.5\% N-alkyl dimethyl-benzylammonium HCL and 5.5\% glutaraldehyde), and the combination of both agents produced higher antimicrobial effect (Roy et al. 1993).

Aquaculture steel tanks are vulnerable to the formation of biofilms. In fact, the presence of Vibrio spp. attached to the steel tanks is a frequent and major concern since many species from this genus are pathogens for the animals grown in these tanks and also for the consumer (Haldar 2012). For example, $V$. alginolyticus is an important opportunistic pathogen that causes disease in humans and frequently contaminates marine animals (Mustapha et al. 2013). Because it can form biofilms, $V$. alginolyticus becomes even more difficult to eradicate, and bacteriophages can serve as alternative sanitizing agents. Sasikala and Srinivasan (2016) used bacteriophage VP01 to disrupt $V$. alginolyticus biofilms. The choice of surface material was not steel. Nonetheless, on polystyrene surfaces, a significant reduction in cell count numbers of $56 \%$ and $86 \%$ was achieved using bacteriophage concentrations of $10^{10}$ and $10^{12}$, respectively. 
Little work with bacteriophages has been carried out on biofilm removal from equipment surfaces. To our knowledge, the only reports are related to the use of bacteriophages in water and wastewater filtration systems to control biofouling. These filtration systems are often impaired by biofilm formation. In one study, anthracite and granular activated carbon biofilter systems were artificially contaminated with Pseudomonas aeruginosa (Zhang et al. 2013). A mixture of bacteriophages specific for $P$. aeruginosa was applied only once, on day 136 of this study, and the efficiency of $P$. aeruginosa removal from filters increased by $56 \%$ and $70 \%$, in the anthracite and in the granular activated biofilters, respectively. The bacterium, Delftia tsuruhatensis, isolated from a wastewater treatment plant, was used to form biofilms on a laboratory-scale membrane bioreactor that simulated biofouling on a membrane bioreactor treating wastewater (Bhattacharjee et al. 2015). Biofilm formation was responsible for a water flux on the bioreactor decrease of about $31 \%$ of its capacity. In this case, the use of a lytic bacteriophage specific for $D$. tsuruhatensis led to a flux increase of $70 \%$ of the original.

\section{Application of Bacteriophages to Foods}

Biofilms containing spoilage and pathogenic microorganisms can lead to serious problems, compromising the quality and safety of food products. Foods can become contaminated at any stage of the food chain, and cleaning and disinfection procedures may not be effective in the elimination of microbial contaminants (Sampathkumar et al. 2005; Pereira and Melo 2009; Gutiérrez et al. 2016). The use of bacteriophages is one of the alternatives to the traditionally used methods in the elimination of biofilms in food settings. Several studies have been conducted using bacteriophages directly on food products (see $>$ "Food Safety and Bacteriophages"). Even though the majority of the studies that are addressed in this section do not imply an application of bacteriophages to control and remove biofilm structures, many studies were included because the presence of surface-attached bacteria may be inferred. The criteria for inclusion of the works were (i) works performed with adhered cells which display no increase of cells throughout time in the untreated control samples since these cells, which probably mimic biofilm detached cells, persist attached to surfaces and are involved in many cross-contamination events and many times can themselves lead to the development of biofilms and (ii) works where the authors have in vitro contaminated their products with bacteria in the absence of any remaining liquid media that could promote their planktonic growth and where the untreated samples (controls) register an increase in the number of cells throughout time (i.e., if there is insufficient liquid within which bacteria can be planktonic, then we assume that the bacteria are not planktonic). We have assumed, although no microscopy studies are presented by the authors, that these might be biofilm-related (Fig. 6). 


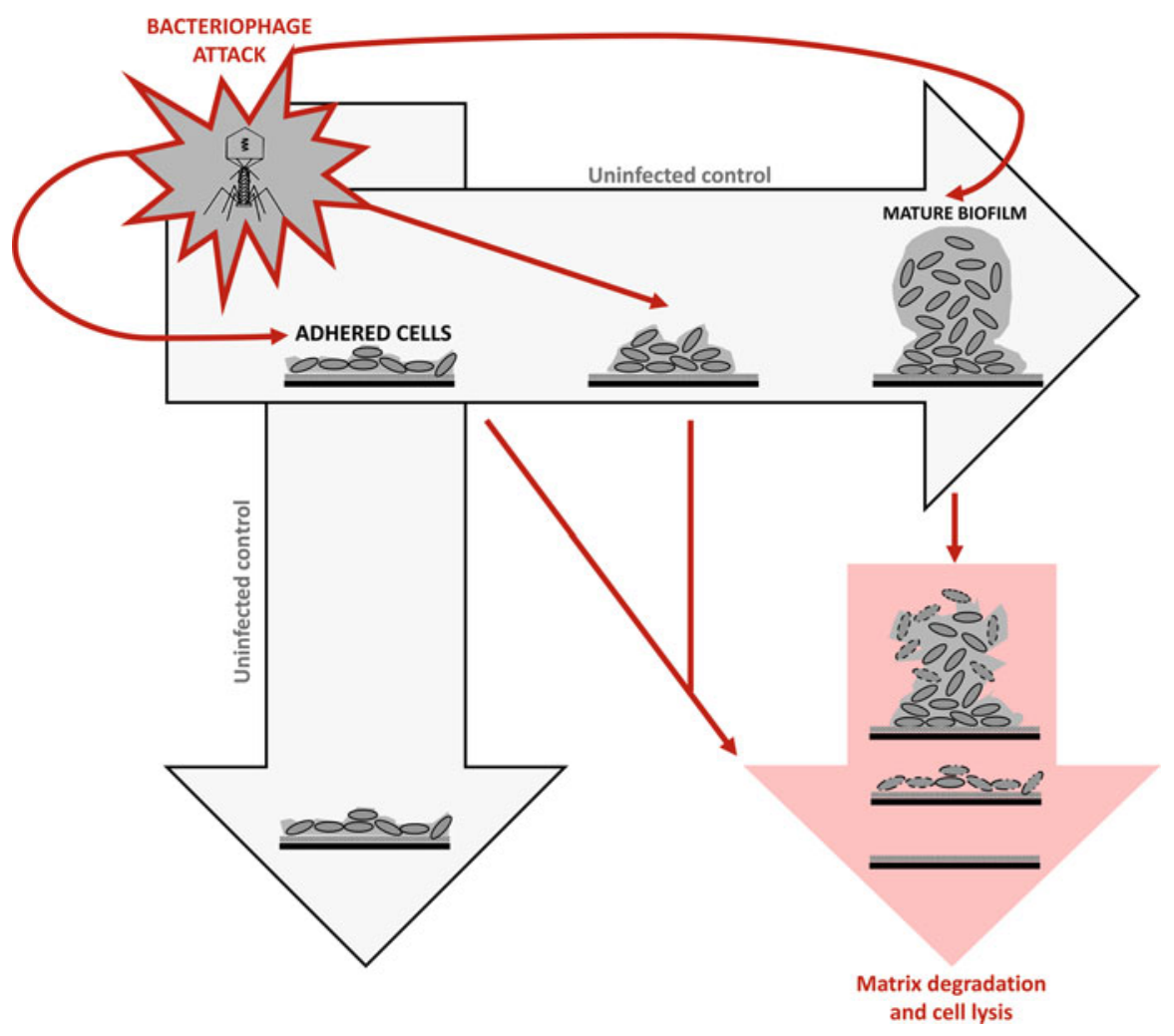

Fig. 6 Target bacterial cell types present in foods and surfaces that have been challenged with bacteriophages

\section{Fresh-Cut Fruits and Vegetables}

Fresh-cut fruit and vegetable products are widely available packaged items and can be already trimmed, peeled, and/or cut offering consumers a high nutrition product that keeps its flavor and freshness. Major focus has been given to E. coli $\mathrm{O} 157: \mathrm{H} 7$ (Table 2), a major foodborne pathogen which is commonly found contaminating fresh produce. Many of these studies were carried out on in vitro contaminated foods where the bacteria remained adhered and did not increase in concentration throughout the experiments. Some commercially available bacteriophage products have been tested in fresh-cut fruits and vegetables. This is the case of EcoShield ${ }^{\mathrm{TM}}$ and ListShield $^{\mathrm{TM}}$, two bacteriophage mixtures available from Intralytix, Inc., designed for treating foods that are at risk of E. coli $\mathrm{O} 157: \mathrm{H} 7$ and L. monocytogenes contamination. The latter can also be used to reduce L. monocytogenes levels from non-food contact equipment, surfaces, etc. in the food processing plants and other food establishments.

In a study conducted by Carter et al. (2012), EcoShield ${ }^{\mathrm{TM}}$ was used for reduction of E.coli on lettuce, and it was observed that this product significantly reduced 
Table 2 Bacteriophage publications for inhibiting cell adhesion and consequent biofilm formation in fresh-cut fruits and vegetables

\begin{tabular}{|c|c|c|c|}
\hline \multicolumn{4}{|c|}{ Fresh-cut fruits and vegetables } \\
\hline Bacteria; surface & $\begin{array}{l}\text { Bacteriophage or } \\
\text { bacteriophage } \\
\text { cocktail }\end{array}$ & $\begin{array}{l}\text { Treatment efficacy (reduction of } \\
\text { viable cells) }\end{array}$ & Reference \\
\hline \multicolumn{4}{|c|}{ Bacteriophage application to adhered cells } \\
\hline $\begin{array}{l}\text { E. coli } \mathrm{O} 157: \mathrm{H} 7 \\
\text { spinach leaves }\end{array}$ & $\begin{array}{l}\text { vB_EcoS_FFH_1, } \\
2 \text { and } 3 \text { cocktail }\end{array}$ & $\begin{array}{l}\text { Reduction of } 3.28,2.88 \text {, and } \\
2.77 \log _{10} \text { at RT for } 24,48 \text {, and } \\
72 \mathrm{~h} \text {, respectively }\end{array}$ & $\begin{array}{l}\text { Hong et al. } \\
(2014)\end{array}$ \\
\hline $\begin{array}{l}\text { E. coli } \mathrm{O} 157: \mathrm{H} 7 \\
\text { cut green pepper } \\
\text { and spinach leaves }\end{array}$ & OSY-SP & $\begin{array}{l}\text { Decrease of } 2.4-3.0 \log _{10} \text {, on } \\
\text { cut green pepper, and } 3.4-3.5 \\
\log _{10} \text {, on spinach leaves, during } \\
72 \mathrm{~h} \text { storage }\end{array}$ & $\begin{array}{l}\text { Snyder } \\
\text { et al. (2016) }\end{array}$ \\
\hline $\begin{array}{l}\text { E. coli } \mathrm{O} 157: \mathrm{H} 7 \\
\text { lettuce }\end{array}$ & EcoShield $^{\mathrm{TM}}$ cocktail & $\begin{array}{l}\text { Reduction of } 87 \% \text { after } 5 \text { min of } \\
\text { contact }\end{array}$ & $\begin{array}{l}\text { Carter et al. } \\
(2012)\end{array}$ \\
\hline $\begin{array}{l}\text { E. coli } \mathrm{O} 157: \mathrm{H} 7 \\
\text { leafy greens }\end{array}$ & EcoShield ${ }^{\mathrm{TM}}$ cocktail & $\begin{array}{l}\text { At } 4 \text { and } 10{ }^{\circ} \mathrm{C} \text { reductions in the } \\
\text { range of } 1.19-4.34 \log _{10} \text { under } \\
\text { atmospheric air and modified } \\
\text { atmosphere }\end{array}$ & $\begin{array}{l}\text { Boyacioglu } \\
\text { et al. (2013) }\end{array}$ \\
\hline $\begin{array}{l}\text { L. monocytogenes; } \\
\text { lettuce and apple }\end{array}$ & ListShield $^{\mathrm{TM}}$ cocktail & $\begin{array}{l}\text { Reduction of } 1 \log _{10} \text { on both } \\
\text { produces }\end{array}$ & $\begin{array}{l}\text { Perera et al. } \\
(2015)\end{array}$ \\
\hline \multicolumn{4}{|c|}{ Bacteriophage application to prevent biofilm formation } \\
\hline $\begin{array}{l}\text { L. monocytogenes; } \\
\text { honeydew melon }\end{array}$ & $\begin{array}{l}\text { LM-103 and } \\
\text { LMP-102 cocktails } \\
\text { alone or in } \\
\text { combination with } \\
\text { nisin }\end{array}$ & $\begin{array}{l}\text { Reduction by } 2-4.6 \log _{10} \text { using } \\
\text { bacteriophage; combination of } \\
\text { bacteriophage with nisin } \\
\text { reduced counts up to } 5.7 \log _{10} \\
\text { on honeydew melon slices }\end{array}$ & $\begin{array}{l}\text { Leverentz } \\
\text { et al. }(2003)\end{array}$ \\
\hline $\begin{array}{l}\text { L. monocytogenes; } \\
\text { cabbage, lettuce }\end{array}$ & $\begin{array}{l}\text { A511 and Listex } \\
\text { P100 }\end{array}$ & $\begin{array}{l}\text { Decrease of } 2.3 \log _{10} \text { and } \\
\text { approx. } 5 \log _{10} \text { in cabbage and } \\
\text { lettuce leaves }\end{array}$ & $\begin{array}{l}\text { Guenther } \\
\text { et al. (2009) }\end{array}$ \\
\hline $\begin{array}{l}\text { E. coli } \mathrm{O} 157: \mathrm{H} 7 \\
\text { cabbage leaves }\end{array}$ & HY01 & $\begin{array}{l}\text { Reduction }>2 \log _{10} \text {, after } 2 \mathrm{~h} \text { of } \\
\text { treatment }\end{array}$ & $\begin{array}{l}\text { Lee et al. } \\
(2016)\end{array}$ \\
\hline $\begin{array}{l}S . \text { Enteritidis; } \\
\text { honeydew melon }\end{array}$ & SCPLX-1 cocktail & $\begin{array}{l}\text { Reduction of } 3.5 \log _{10} \text { at } \\
\text { temperatures ranging from } 5 \text { to } \\
20^{\circ} \mathrm{C}\end{array}$ & $\begin{array}{l}\text { Leverentz } \\
\text { et al. (2001) }\end{array}$ \\
\hline
\end{tabular}

bacterial loads by $87 \%$ after only 5 min of contact. In another study, EcoShield ${ }^{\mathrm{TM}}$ was applied on fresh-cut leafy greens, under atmospheric air or modified atmosphere $\left(\left(5 \% \mathrm{O}_{2}, 35 \%, \mathrm{CO}_{2}\right.\right.$, and $\left.60 \% \mathrm{~N}_{2}\right)$ (Boyacioglu et al. 2013). Although this bacteriophage cocktail was effective in reducing $E$. coli $\mathrm{O} 157: \mathrm{H} 7$ levels on fresh-cut lettuce and spinach under atmospheric air, this reduction was even greater when EcoShield $^{\mathrm{TM}}$ was applied under modified atmosphere conditions. Hong et al. (2014) used a mixture of three bacteriophages to reduce E. coli $\mathrm{O} 157: \mathrm{H} 7$ on the surface of spinach leaves. They observed a reduction of 3.28, 2.88, and $2.77 \log _{10}$ $\mathrm{CFU} / \mathrm{ml}$ when spinach was stored at room temperature for 24,48 , and $72 \mathrm{~h}$, respectively. Cut green pepper and spinach leaves were artificially contaminated with $E$. coli $\mathrm{O} 157: \mathrm{H} 7$ and challenged with bacteriophage OSY-SP, which lead to a 
decrease of the bacterial load by 2.4-3.0 $\log _{10} \mathrm{CFU} / \mathrm{g}$ on cut green pepper and 3.4-3.5 $\log _{10} \mathrm{CFU} / \mathrm{g}$ on spinach leaves (Snyder et al. 2016).

Also, reduction of adhered L. monocytogenes on lettuce and apples was attempted with ListShield ${ }^{\mathrm{TM}}$, a commercially available bacteriophage cocktail (Intralytix, Inc.) (Perera et al. 2015). The antibacterial effect with ListShield ${ }^{\mathrm{TM}}$, reduced L. monocytogenes loads on both products by $1 \log _{10}$.

A few studies that initially start with bacteria spiked on foods register a high increase of bacterial numbers in the samples untreated with bacteriophage. Leverentz et al. (2001) used a mixture of four bacteriophages (SCPLX-1, Intralytix, Inc.) to reduce Salmonella Enteritidis population on the surface of several fresh-cut melons and apples, at different temperatures $\left(5,10\right.$, and $\left.20^{\circ} \mathrm{C}\right)$. Although they observed a significant reduction of the bacterial load on melon slices, the same was not observed for apple slices, probably due the low $\mathrm{pH}$ of this fruit.

For the elimination of L. monocytogenes also from the surface of melon and apple slices, the bacteriophage mixtures LM-103 and LMP-102, provided by Intralytix, Inc., were applied (Leverentz et al. 2003). Similar results to the study with SCPLX-1 cocktail were obtained, with the bacteriophage mixtures able to reduce the number of L. monocytogenes bacteria on the surface of melon but unable to do so on apple slices. Also of L. monocytogenes, broad host-range bacteriophages A511 and Listex $^{\mathrm{TM}}$ regarding the elimination P100 were used on the surface of cabbage and lettuce (Guenther et al. 2009), and both bacteriophages caused greater than $2 \log _{10}$ cell reductions.

Bacteriophage HY01, capable of lysing E. coli O157:H7 and S. flexneri, was applied on cabbage leaves and was able to inhibit the food isolate strain $E$. coli $\mathrm{O} 157$ : H7 ATCC 43895 for up $2 \mathrm{~h}$. Bacterial recovery, however, was observed after $2 \mathrm{~h}$ of incubation (Lee et al. 2016).

\section{Red and Poultry Meats}

Another important source of food-related outbreaks is meat (poultry, pig, and bovine) (European Food Safety Authority 2015). Campylobacter, E. coli, and Salmonella are among the most frequently recovered pathogens from poultry skin and meat and therefore a focus of many bacteriophage studies (Table 3).

Bacteriophages have been applied on artificially $C$. jejuni contaminated chicken pieces (frozen and unfrozen) and reduced adhered bacterial counts by approximately $1 \log _{10}$ (Atterbury et al. 2003). In another study, bacteriophage 12,673 was applied on chicken skin portions, and C. jejuni counts were reduced by approximately $95 \%$ compared to controls, which continued to multiply on the skin (Goode et al. 2003) and possibly formed 3D biofilm structures.

Bacteriophages have been used to control/eradicate adhered Salmonella enterica serovars Typhimurium and Enteritidis from different meat products. A cocktail of bacteriophages (Felix 01, ФSH17, ФSH18, and $\Phi$ SH19) applied on pig skin samples at multiplicities of infection (MOI) of 10 or greater reduced $S$. Typhimurium (Salmonella enterica subsp. enterica serovar Typhimurium) present on pig skin samples up to $2 \log _{10}$ during a period of $96 \mathrm{~h}$ (Hooton et al. 2011). In another $S$. Typhimurium bacteriophage study, hot dogs and sliced turkey samples were 
Table 3 Bacteriophage works targeting adhered cells and biofilm prevention in red meat and poultry

\begin{tabular}{|c|c|c|c|}
\hline \multicolumn{4}{|l|}{ Red and poultry meats } \\
\hline Bacteria; surface & $\begin{array}{l}\text { Bacteriophage or } \\
\text { bacteriophage cocktail }\end{array}$ & $\begin{array}{l}\text { Treatment efficacy (reduction of } \\
\text { viable cells) }\end{array}$ & Reference \\
\hline \multicolumn{4}{|c|}{ Bacteriophage application to adhered cells } \\
\hline C. jejuni; chicken skin & $\varphi 2$ & $\begin{array}{l}\text { Reduction by approximately } \\
1 \log _{10} ; \text { greater reductions on } \\
\text { frozen chicken skin pieces }\end{array}$ & $\begin{array}{l}\text { Atterbury } \\
\text { et al. (2003) }\end{array}$ \\
\hline $\begin{array}{l}\text { Salmonella } \\
\text { Typhimurium; pig skin }\end{array}$ & $\begin{array}{l}\text { Felix 01, ФSH17, } \\
\Phi S H 18, \text { and } \Phi S H 19 \\
\text { cocktail }\end{array}$ & $\begin{array}{l}\text { MOIs equal or greater than } \\
10 \text { reduced up to } 2 \log _{10} \text {, during a } \\
\text { period of } 96 \mathrm{~h}\end{array}$ & $\begin{array}{l}\text { Hooton } \\
\text { et al. (2011) }\end{array}$ \\
\hline $\begin{array}{l}\text { S. Typhimurium; hot } \\
\text { dogs and sliced Turkey }\end{array}$ & FO1-E2 & $\begin{array}{l}\text { Reduction to undetectable levels } \\
\text { after } 2 \text { days of incubation. } \\
\text { Bacteriophage resistant bacteria } \\
\text { appeared at day } 6\end{array}$ & $\begin{array}{l}\text { Guenther } \\
\text { et al. (2012) }\end{array}$ \\
\hline $\begin{array}{l}S \text {. Typhimurium and } S \text {. } \\
\text { Enteritidis; chicken } \\
\text { breasts }\end{array}$ & $\begin{array}{l}\text { UAB Phix }(x=20 \\
78,87) \text { cocktail }\end{array}$ & $\begin{array}{l}\text { Reduction of } 2.2 \text { and } 0.9 \log _{10} \\
\text { respectively, on chicken breasts }\end{array}$ & $\begin{array}{l}\text { Spricigo } \\
\text { et al. (2013) }\end{array}$ \\
\hline $\begin{array}{l}S . \text { Typhimurium, } S \text {. } \\
\text { Heidelberg and } S . \\
\text { Enteritidis; chicken } \\
\text { meat and skin }\end{array}$ & $\begin{array}{l}\text { SalmoFresh } \\
\text { combined with lauric } \\
\text { arginate or } \\
\text { cetylpyridinum } \\
\text { chloride }\end{array}$ & $\begin{array}{l}\text { Combined treatment reduced cell } \\
\text { counts up to } 5 \log _{10} \text {, on chicken } \\
\text { skin, and up to } 1.3 \log _{10} \text {, on } \\
\text { chicken meat }\end{array}$ & $\begin{array}{l}\text { Sukumaran } \\
\text { et al. (2015) }\end{array}$ \\
\hline $\begin{array}{l}\text { S. Enteritidis; chicken } \\
\text { skin }\end{array}$ & wksl13 & $\begin{array}{l}\text { Reduction of } 3.04 \log _{10} \text {, after } \\
24 \text { h storage at } 8{ }^{\circ} \mathrm{C}\end{array}$ & $\begin{array}{l}\text { Kang et al. } \\
(2013)\end{array}$ \\
\hline E. coli $\mathrm{O} 157: \mathrm{H} 7$; beef & EcoShield $^{\mathrm{TM}}$ cocktail & $\begin{array}{l}\text { Levels reduced by more than } \\
94 \%\end{array}$ & $\begin{array}{l}\text { Carter et al. } \\
(2012)\end{array}$ \\
\hline E. coli $\mathrm{O} 157: \mathrm{H} 7$; beef & $\begin{array}{l}\mathrm{T} 5, \mathrm{~T} 1, \mathrm{~T} 4 \text { and } \mathrm{O} 1 \\
\text { individually or in } \\
\text { cocktail }\end{array}$ & $\begin{array}{l}\text { Alone or in cocktail caused } \\
\text { significant reductions at all } \\
\text { temperatures and MOIs tested }\end{array}$ & $\begin{array}{l}\text { Liu et al. } \\
\text { (2015) }\end{array}$ \\
\hline $\begin{array}{l}\text { L. monocytogenes; } \\
\text { roast beef and cooked } \\
\text { Turkey }\end{array}$ & $\begin{array}{l}\text { Listex } \\
\text { combined with } \\
\text { potassium lactate and } \\
\text { sodium diacetate }\end{array}$ & $\begin{array}{l}\text { Treatment of } L . \text { monocytogenes } \\
\text { contaminated meat with } \\
\text { bacteriophage improved the } \\
\text { efficiency of the used chemical } \\
\text { compounds }\end{array}$ & $\begin{array}{l}\text { Chibeu } \\
\text { et al. (2013) }\end{array}$ \\
\hline $\begin{array}{l}\text { L. monocytogenes; hot } \\
\text { dogs, sliced cooked } \\
\text { Turkey }\end{array}$ & $\begin{array}{l}\text { A511 and Listex } \\
\text { P100 }\end{array}$ & $\begin{array}{l}\text { Decrease of } 2.2 \log _{10} \text { and } 1.5 \\
\log _{10} \text { of Scott A strain present in } \\
\text { hot dogs and sliced Turkey, } \\
\text { respectively }\end{array}$ & $\begin{array}{l}\text { Guenther } \\
\text { et al. (2009) }\end{array}$ \\
\hline \multicolumn{4}{|c|}{ Bacteriophage application to prevent biofilm formation } \\
\hline $\begin{array}{l}S \text {. Typhimurium and } S \text {. } \\
\text { Enteritidis; pig skin } \\
\text { and chicken breasts }\end{array}$ & $\begin{array}{l}\text { UAB_Phix }(x=20 \\
78,87) \text { cocktail }\end{array}$ & $\begin{array}{l}\text { Reduction of } 4 \text { and } 2 \log _{10} \text { of } S \text {. } \\
\text { Typhimurium and Enteritidis, } \\
\text { respectively, on pig skin }\end{array}$ & $\begin{array}{l}\text { Spricigo } \\
\text { et al. (2013) }\end{array}$ \\
\hline C. jejuni; chicken skin & NCTC 12673 & $\begin{array}{l}\text { Bacterial loads reduced by nearly } \\
95 \%\end{array}$ & $\begin{array}{l}\text { Goode et al. } \\
(2003)\end{array}$ \\
\hline $\begin{array}{l}S \text {. Typhimurium; } \\
\text { chicken breasts }\end{array}$ & $\begin{array}{l}\mathrm{BPS} x(x=2 \mathrm{H} 1,7 \mathrm{~T} 1, \\
8 \mathrm{H} 2,11 \mathrm{Q} 3,11 \mathrm{~T} 1, \\
11 \mathrm{~T} 2, \text { and } 15 \mathrm{Q} 2) \\
\text { cocktail }\end{array}$ & $\begin{array}{l}\text { Undetectable numbers after } 1 \text { day } \\
\text { of incubation }\end{array}$ & $\begin{array}{l}\text { Han et al. } \\
\text { (2017) }\end{array}$ \\
\hline
\end{tabular}


artificially contaminated and challenged with bacteriophage FO1-E2 (Guenther et al. 2012), and although counts dropped to undetectable levels after 2 days of incubation with FO1-E2, bacteriophage-resistant bacteria appeared after 6 days. A bacteriophage cocktail composed of UAB_Phi20, AB_Phi78, and UAB_Phi87 bacteriophages had its effectiveness tested in pig skin and chicken breasts artificially contaminated with $S$. enterica serovars Typhimurium and Enteritidis (Spricigo et al. 2013). Significant bacterial reductions were obtained for both serovars on the two food products tested; however, the results are presented separately in Table 3 according to the behavior of the untreated samples. Bacteriophage wksl13, a broadspectrum bacteriophage infecting $S$. Enteritidis (Salmonella enterica subsp. enterica serovar Enteritidis) and $S$. Typhimurium, was used for the control of $S$. Enteritidis on the surface of chicken skin samples (Kang et al. 2013). With a single-dose application of this bacteriophage, bacterial counts were reduced in $3.04 \log _{10}$ after $24 \mathrm{~h}$ of storage at $8{ }^{\circ} \mathrm{C}$, with no significant regrowth during the next 7 days. Unlike the other experiments described where cells only remained adhered and did not increase in number, more recently a study evaluated the antimicrobial activity of a bacteriophage cocktail, composed of seven bacteriophages against $S$. Typhimurium on chicken breasts (Han et al. 2017). At all tested temperatures, bacterial loads in untreated samples increased significantly while bacterial loads were reduced to undetectable, at temperatures above $8{ }^{\circ} \mathrm{C}$ after 1 day in contact with the bacteriophage cocktail.

EcoShield ${ }^{\mathrm{TM}}$ was successfully used to reduce the levels of E. coli $\mathrm{O} 157: \mathrm{H} 7$ in experimentally contaminated beef by more than $94 \%$ (Carter et al. 2012). Also, the efficacy of four E. coli O157:H7-specific bacteriophages, T5-like (T5, T1-like (T1), T4-like (T4), and O1-like (O1) was tested, individually or as a cocktail in beef samples (Liu et al. 2015). T5-like bacteriophage was the most efficient bacteriophage. Nevertheless, all bacteriophages were able to significantly reduce E. coli levels at all temperatures and multiplicities of infection tested.

\section{Dairy Products}

The dairy industry is commonly affected by microbial contamination that results from inappropriate disinfection of equipment, with L. monocytogenes being one of the most common foodborne pathogens responsible for these contaminations (European Food Safety Authority 2015). ListShield ${ }^{\mathrm{TM}}$ and Listex ${ }^{\mathrm{TM}}$ P100 and A511 have been tested on soft and hard cheeses as well as mozzarella cheese brine, to reduce the counts of adhered bacteria. ListShield ${ }^{\mathrm{TM}}$ applied on experimentally contaminated hard cheese was capable of reducing bacterial contamination by $0.7 \log$ after 5 min of treatment (Perera et al. 2015). Listex ${ }^{\mathrm{TM}}$ P100 was tested on the surface of Minas Frescal and Coalho hard cheeses and was responsible for a bacterial population reduction of $2.3 \log _{10}$, in Minas Frescal cheese, and $2.1 \log _{10}$, in Coalho cheese (Silva et al. 2014). Listex ${ }^{\mathrm{TM}} \mathrm{P} 100$ and A511 were tested in mozzarella cheese brine individually, and both bacteriophages decreased L. monocytogenes more than $5 \log _{10}$.

L. monocytogenes targeted by Listex ${ }^{\mathrm{TM}} \mathrm{P} 100$, applied on the surface of contaminated soft cheeses, reduced Listeria by at least $3.5 \log _{10}$ to complete eradication 
(Carlton et al. 2005). In another study, different types of soft-ripened cheeses were artificially contaminated with $L$. monocytogenes and challenged with broad-host bacteriophage A551 (Guenther and Loessner 2011). This bacteriophage was able to eradicate bacterial cells from the cheese surfaces to levels under $1 \mathrm{CFU} / \mathrm{cm}^{2}$ (detection limit) when the initial contamination rate was of $10^{2} \mathrm{CFU} / \mathrm{cm}^{2}$ or less, and when higher contamination rates were applied $\left(10^{3} \mathrm{CFU} / \mathrm{cm}^{2}\right)$, a significant reduction of almost $3 \log _{10}$ was observed.

\section{Single Bacteriophage Versus Cocktail Approach and Other Approaches}

Since industrial environments have a range of species distressing the food sector and since multispecies biofilm consortia are present (Flemming et al. 2016), in order to target a higher number of species, the use of bacteriophage cocktails should be considered. A major advantage of using a bacteriophage cocktail is that it can act on a broader range of hosts. Also, the use of bacteriophage cocktails decreases the probability of emergence of bacteriophage-resistant bacteria. Several studies have been performed using bacteriophages as biosanitizers, as presented above, but only a few describe the antibacterial effect of the individual bacteriophages in a cocktail versus the cocktail bacteriophage result. As previously mentioned, elimination of E. coli $\mathrm{O} 157: \mathrm{H} 7$ from beef has been tested with four bacteriophages individually and in cocktail (Liu et al. 2015). The T5-like bacteriophage had better efficacy than the cocktail in all experiments with a MOI of 1000 and 4,22 , and $37^{\circ} \mathrm{C}$ temperatures. Contrary to what was predicted, the cocktail had a lower efficacy which the authors suggested was due to competitive interference among bacteriophages. This result clearly shows that designing effective cocktails is challenging and if the bacteriophages are not tested individually, then the overall efficacy of the cocktail can be lower than the effect of one of the single bacteriophages present in the cocktail. In another work published by Arachchi et al. (2013), three bacteriophages, LiMN4L, LiMN4p, and LiMN17, were applied individually or in cocktail for the elimination of L. monocytogenes on stainless steel coupons. Contrary to the results from Liu et al. (2015), single bacteriophages reduced bacterial cells by $3-4.5 \log _{10}$, and the cocktail was responsible for a much higher antibacterial effect $\left(3.8-5.4 \log _{10}\right)$, which clearly reflects the differences between the bacteriophages used in the aforementioned work.

Some studies have also combined bacteriophages with other agents. For instance, bacteriophage activity combined with quaternary ammonium compounds (QACs), widely used disinfectants in the food industry, was tested against Listeria by Roy et al. (1993) who used QUATAL (a product containing 10.5\% N-alkyldimethylbenzylammonium HCL and 5.5\% glutaraldehyde as active ingredients, Ecochimie Ltée, Quebec, Canada). Disinfection of stainless steel and polypropylene surfaces contaminated with $L$. monocytogenes biofilms was tested with bacteriophages $\mathrm{H} 387$, H387-A, and 2671 and their combination with QUATAL. The efficiency of these agents in combination was higher compared to the use of either one individually. 
Another combinatorial work tested bacteriophages and chlorine, a chemical compound extensively applied in the disinfection of industrial work surfaces, to remove of Pseudomonas biofilms. The Pseudomonas bacteriophage-chlorine mixture worked synergistically in the control and removal of $P$. aeruginosa biofilms (Zhang and $\mathrm{Hu}$ 2013). The effectiveness of combining bacteriophages with chemical antimicrobials has also been verified on the surface of several foods. Chibeu et al. (2013) tested the efficacy of anti-Listeria bacteriophage preparation Listex ${ }^{\mathrm{TM}} \mathrm{P} 100$ in reducing $L$. monocytogenes on the surface of RTE roast beef and cooked turkey, combined with chemical compounds potassium lactate and sodium diacetate. This study showed that the use of Listex ${ }^{\mathrm{TM}} \mathrm{P} 100$ on L. monocytogenes adhered cells improved the efficiency of the used chemical compounds. The reduction of different Salmonella strains on chicken meat and chicken skin by combined application of the bacteriophage preparation SalmoFresh ${ }^{\mathrm{TM}}$ with lauric arginate or cetylpyridinium chloride was evaluated (Sukumaran et al. 2015). This treatment led to significant bacterial load reductions when compared to the application of each product alone. In this way, the examples mentioned above demonstrate that, although bacteriophages have been proven to be efficient in the elimination of biofilms in different industrial settings, their combined use with different chemical antimicrobials can potentiate both products' efficiency, since bacteriophages very likely disrupt the biofilm's structure, leaving it more susceptible to the action of chemical compounds.

\section{Challenges that Bacteriophages Face in Industrial Environments}

Bacteriophage application in industrial environments is challenging since many conditions can lead to their inactivation. For instance, bacteriophages encounter sanitizers and disinfectants that can impair their viability. Several studies have assessed Lactococcus lactis bacteriophage viability in commercial sanitizers (foodgrade chemicals included oxidizing agents, halogenated agents, alcohols, quaternary ammonium compounds, anionic acids, iodine-based acids, and an amphoteric chemical) and disinfectants. L. lactis bacteriophages are a problem in the dairy industry (see " "Industrial Processes Involving Bacteriophages") because L. lactis strains are particularly vulnerable to members of the so-called 936 group of phages, and therefore their removal is desirable which can only be accomplished using strict sanitization and disinfection with appropriate biocidal solutions. Several bacteriophages possess resistance to specific biocides or biocide types, and the ones showing resistance also tend to possess a broad tolerance to multiple classes of antimicrobial compounds. Many chemical compounds, such as benzalkonium chloride (BAC), a quaternary ammonium compound (QAC), completely eliminated bacteriophages at concentrations of just $0.1 \% \mathrm{w} / \mathrm{v}$ after $30 \mathrm{~min}$ (Campagna et al. 2014; Hayes et al. 2017). Although not as efficient as BAC, hydrogen peroxide also is able to cause complete bacteriophage inactivation, but for this it requires high concentrations $(20 \%(\mathrm{v} / \mathrm{v}))$. A QAC-based disinfectant designed for surface cleaning in the food and dairy industry was tested in L. lactis bacteriophages, and the product was highly effective in destroying bacteriophages (Hayes et al. 2017). The several types of 
commercial sanitizers and disinfectants containing various chemical agents differ in $\mathrm{pH}$ according to their active agent. For instance, acid anionic and carboxylic acid products have $\mathrm{pH}$ values as low as 2 , and the $\mathrm{pH}$ range of QACs and phenolic compounds varies in the range of 3-10.5 and 3-9.5, respectively (Richter and Cords 2001). The acidic $\mathrm{pH}$ conditions of many of these products are the main cause of bacteriophage inactivation. For instance, many bacteriophages do not survive $\mathrm{pH}$ lower than 4.5, such as T4 and PM2, among others (Ly-Chatain 2014).

The EPA has performed an extensive study on the role of UV radiation on the inactivation of viruses and bacteriophages with different size and genomic composition (Shin et al. 2005). Some viruses rapidly became inactivated by low levels of UV. Nevertheless, although bacteriophage MS2 also suffered inactivation to some extent (2-log inactivation), the UV dose required for such reduction was high $\left(30 \mathrm{~mJ} / \mathrm{cm}^{2}\right)$. Large DNA viruses, such as adenovirus 2, also resist inactivation and for a $2 \log _{10}$ reduction they require an UV dose of $60 \mathrm{~mJ} / \mathrm{cm}^{2}$. This behavior cannot however be transposed to bacteriophages since large DNA bacteriophages were rapidly inactivated (more than $5 \log _{10}$ ) with a small dose of $10 \mathrm{~mJ} / \mathrm{cm}^{2}$. Inactivation by UV is therefore a challenge for bacteriophage application in industrial environments where UV is used as a disinfecting agent, and as the EPA's report demonstrates, bacteriophage inactivation by $\mathrm{UV}$ is not strictly virus size nor type dependent.

High-pressure processing (HPP) is a nonthermal method applied to foods that inactivates harmful pathogens and vegetative spoilage microorganisms using intensive pressure (400-600 MPa). In the dairy industry, HPP is usually used on milk, though it is known to have great influence in the physicochemical and technological properties of milk (e.g., casein micelles are disintegrated, whey protein hydrophobicity is modified, color is affected, etc.) (Chawla et al. 2011). To warrant minimal effects on taste, texture, appearance, or nutritional value, the process is usually run at $<45{ }^{\circ} \mathrm{C}$. HHP is known to inactivate unwanted L. lactis bacteriophages (Guglielmotti et al. 2012), and also norovirus (Kingsley et al. 2007), in the pressure-temperature region of $0.1-600 \mathrm{MPa}$ and $25-80^{\circ} \mathrm{C}$. However, some bacteriophages can withstand these high-pressure conditions, such as two temperate L. paracasei bacteriophages (Mercanti et al. 2012). If HPP becomes a "musthave" technology in dairy industry, then there will be a need to select bacteriophages, where these are to be used, that can survive these conditions. The same bacteriophage selection needs to be performed if bacteriophages are to be applied in shellfish to target Vibrio sp. since HHP is an increasingly popular method of separating shellfish meat from the shell for molluscan shellfish (Kingsley 2014).

The difficulty of applying a bacteriophage product for general cleaning is challenged by the massive microbial variety. Unlike in clinical settings, where an infection can be the result of a single species or a multispecies consortia (Kujiraoka et al. 2017; Ruppé et al. 2017), this is not the case as observed in industry. The presence of several other non-susceptible bacteria, debris, dust, etc. limits the bacteriophage-host interactions, making bacteriophage therapy a difficult option for many food industry environments. Also, bacteriophages do not find their host under the optimal growth conditions, which can have a major impact in 
effectiveness. It is known that faster-growing cells support a faster bacteriophage growth, mostly due to the number of ribosomes and to a lesser extent due to the ribosome elongation rates (You et al. 2002). Adhered and biofilm cells may not be in an ideal exponential phase as with many of the studies that are performed in the laboratories.

Despite all these challenges, the few biofilm studies described demonstrate that bacteriophages have a potential role in the reduction of adhered and biofilm cells from foods and food contact surfaces. Their application to food industry can be effective, however, and bacteriophages complemented with other technology (disinfectants, biocides, HPP, etc.) will possibly have better antimicrobial effect and consequently contribute to food safety.

\section{Bacteriophages and Biofilms in the Clinical Setting}

\section{Background}

Biofilms, in which colonies of bacteria are embedded in a complex extracellular matrix derived from the bacteria themselves, are extremely common adaptations that allow bacteria to increase their resistance to a broad range of environmental challenges. Unsurprisingly, this protection is also important in clinical disease. It has been reported that biofilms are associated with up to $80 \%$ of bacterial infections (Bjarnsholt et al. 2018), and they are known to be a marker of chronic infections where they aid in the persistence of bacteria (Abedon 2016, 2018a).

Biofilms are known to decrease greatly the effects of antibiotics and other chemical treatments (Ceri et al. 1999) and, along with metabolic factors, play an important role in the developing crisis of antimicrobial resistance (see $>$ "Introduction: Bacteriophages in the Era of Antibiotic Resistance"). It is important to note that a single biofilm may shelter not just the bacteria that produce it, but other, coinfecting bacteria (and other microorganisms) as well, although the population dynamics of such systems are as yet poorly understood.

\section{Bacteriophage-Biofilm Interactions}

Understanding of the complex interactions between bacteriophages and biofilms is limited. One significant issue in understanding the nature of the bacteriophagebiofilm interaction is that many studies of biofilms are conducted in vitro, with relatively immature biofilms (Ceri et al. 1999; Harper et al. 2014) often containing a single bacterial species. It has been suggested that multispecies biofilms may prove more refractory to bacteriophage-mediated eradication (Tait et al. 2002), possibly by allowing other bacterial species to fill cleared zones. In contrast, others have demonstrated effective control of multispecies biofilms (Sillankorva et al. 2011). It is clear that however such studies are conducted, it is unlikely that the complexity of in vivo biofilms will be easily modelled in vitro. 
It is now clear as well that the extracellular matrix does not form an impermeable barrier to the diffusion of all antibiotics (Spoering and Lewis 2001), though sequestration of some antibiotics by matrix components is known to occur (Mah et al. 2003). Rather, the combination of a protective extracellular matrix with the presence of highly resistant persister cells allows biofilms to protect at least some of their bacterial contents, thus providing a shielded reservoir from which infection can spread out after a challenge, even if reduced or even eliminated elsewhere in the body.

It has long been known that bacteriophages can target bacteria even within biofilms that can resist antibiotic treatments (Harper et al. 2014). Given the ubiquity of biofilms, it is unsurprising that bacteriophages have developed, over the long and complex coevolution of predator and prey (see "Bacteria-Phage Antagonistic Coevolution and the Implications for Phage Therapy"), the ability to target this rich source of bacterial hosts. In contrast, conventional antibiotics can be rendered almost ineffective even by early stage biofilms (Abedon 2015; Ceri et al. 1999; Harper et al. 2014).

Characteristics of bacteriophages that assist with their ability to target bacteria within biofilms include their ability to amplify themselves locally to high levels where their host is present, producing a localized and focused antibacterial effect (Abedon 2015). They also have the ability to infect the biofilm-associated persister cells which, being metabolically inactive, are highly resistant to antibiotics that rely on bacterial metabolism to exert their effects. Bacteriophages can infect these cells, activating and killing these hosts when they resume growth (Pearl et al. 2008). Bacteriophages also can carry, produce, or even induce the production of enzymes to degrade the biofilm matrix (Harper et al. 2014) or can of course simply destroy the bacteria that produce the extracellular matrix, accelerating its degradation by external factors.

Biofilms provide a rich source of target bacteria in close proximity to each other a situation that has been referred to as "spatial vulnerability" (Abedon 2018b). They are thus able, at least potentially, to support higher levels of bacteriophage amplification than more dispersed bacterial populations. In support of this, in some cases, biofilms seem to be more supportive of bacteriophage replication than are planktonic cells (Abedon 2017; Harper et al. 2014).

However, there are also negative features of bacteriophage infection within biofilms. The extracellular matrix can limit bacteriophage diffusion, bacteriophages may become adsorbed to unproductive targets (due to abortive infection or prior cell killing) (Abedon 2018b), and growth may be less rapid in the cells deep inside the biofilm owing to their slower metabolism. To quote Abedon (2018b), regarding the use of bacteriophages against biofilms "phage ability to achieve and sustain sufficient numbers. . .must be empirically verified. . .rather than simply assumed."

As part of this limitation, it has been suggested that optimal bacteriophage activity might be associated with early stage rather than mature biofilms (Abedon 2016; Azeredo and Sutherland 2008; Sillankorva and Azeredo 2014). However, against this it should be noted that bacteriophages have been shown to be effective against long-established infections of a range of targets in situations where biofilms 
are characteristic of the observed pathology (Fish et al. 2016, 2018; Hawkins et al. 2010; Wright et al. 2009). In such situations it is important to remember that other effectors are in play, from conventional antibiotics to the effects of the immune system of the infected host. Biofilms can also shield against such effectors, but their disruption can help to restore susceptibility (Chaudhry et al. 2017; Kumaran et al. 2018; Uchiyama et al. 2018) and aid in clearing even stubborn infections. The complexities of interactions with the immune response are of course very difficult to mimic in vitro.

\section{Applications}

Many of the studies of bacteriophage activity in vivo have targeted infections that are difficult to treat with conventional antibiotics. Unsurprisingly, these are often longterm infections where biofilms are present. Such infections include burn wounds (Phagoburn 2018), chronic otitis (Hawkins et al. 2010; Wright et al. 2009), and lower limb ulcers (Fish et al. 2016, 2018; Rhoads et al. 2009) (see $>$ "Clinical Trials of Bacteriophage Therapeutics"; "The Use of Bacteriophages in Veterinary Therapy").

It is known that very low densities and other factors of their bacterial target can limit the efficacy of bacteriophages, where amplification cannot occur at useful levels (Abedon 2018b; Harper 2018). This can require the use of very high levels of input bacteriophages to produce a useful antibacterial effect where few bacteria are present (see - "Food Safety and Bacteriophages"), and this has been a challenge in some clinical work where the treated area lacks treatment-phage-sensitive bacterial targets (Rose et al. 2014). The identification of suitable targets for the therapeutic use of bacteriophages will clearly require the identification of infections with a number of characteristics (Harper 2018). These include the accessibility of the infection site, as well as the presence of sufficient levels and types of the bacterial host to support bacteriophage amplification.

Alternative phage-based approaches do exist. Work on the use of genetically engineered bacteriophages has been conducted, although these are often designed to be non-replicating, given the complications of using engineered, replicating agents in the clinic (see $>$ "Engineered and Non-replicating Bacteriophage"). Although some early work has been conducted (Fairhead 2009), to date these studies have largely been focused on industrial rather than clinical uses ( $\mathrm{Lu}$ and Collins 2007).

\section{Conclusion}

Clinical work to date has demonstrated, even in the context of a fully regulated, controlled clinical trial (Wright et al. 2009), that bacteriophages can show considerable promise in the control of biofilm-associated infections - in that case chronic otitis caused by Pseudomonas aeruginosa. However, it has been stated that "such applications are still evolving, and ... the identification of the most effective 
approaches has to be, at present, speculative in nature" (Harper et al. 2014). Although work is continuing to explain the complex interactions involved, this speculative nature is still very much the case at the time of writing.

\section{Cross-References}

- Bacteriophages as Biocontrol Agents

- Bacteriophage Use in Molecular Biology and Biotechnology

- Food Safety and Bacteriophages

- Industrial Processes Involving Bacteriophages

- Introduction: Bacteriophages in the Era of Antibiotic Resistance

Acknowledgments This work was supported by the Portuguese Foundation for Science and Technology (FCT) under the scope of the project PTDC/BBB-BSS/6471/2014, the strategic funding of UID/BIO/04469/2013 unit and COMPETE 2020 (POCI-01-0145-FEDER-006684), and under the scope of the Project RECI/BBB-EBI/0179/2012 (FCOMP-01-0124-FEDER027462). This work was also supported by BioTecNorte operation (NORTE-01-0145-FEDER000004) funded by the European Regional Development Fund under the scope of Norte2020 Programa Operacional Regional do Norte. Catarina Milho acknowledges FCT for the grant SFRH/ BD/94434/2013. Sanna Sillankorva is an FCT Investigator (IF/01413/2013).

\section{Glossary}

BAC

Biocides

Biofilm

Biofilm microcolonies

CFU

Cross-contamination

Disinfectants

EPA

EPS
Benzalkonium chloride

The European legislation as a chemical substance or microorganism intended to destroy, deter, render harmless, or exert a controlling effect on any harmful organism by chemical or biological means. US EPA defines biocide as a diverse group of poisonous substances including preservatives, insecticides, disinfectants, and pesticides used for the control of organisms that are harmful to human or animal health or that cause damage to natural or manufactured products

Surface-associated microbial cells that are embedded in a self-produced extracellular polymeric substance matrix

Macroscopically visible clumps of cells

Colony forming units

Product contamination, for instance, as a result of spread of moisture drops and aerosols formed during cleaning and worker's activities

Agent that is applied to inanimate objects to kill some but not necessarily all organisms

Environmental Protection Agency

Extracellular polymeric substances comprising mainly polysaccharides, nucleic and amino acids, glycoproteins 
EPS matrix

Fresh-cut produce

\section{HACCP \\ HHP \\ Mature biofilm}

$\mathrm{mJ}$

MOI

$\mathrm{MPa}$

Multispecies biofilm

Opportunistic

Persister cells

QAC

Quorum sensing

RTE

Sanitizer

Sequestrant and phosphoproteins, sugars, phospholipids, uronic acids, and phenolic compounds

Extracellular polymeric substances matrix that provides mechanical stability, mediate microbial adhesion and forms a 3D polymer network that immobilizes biofilm cells

Any fresh fruit or vegetable that has been physically altered from its original form, but remains in a fresh state Hazard Analysis and Critical Control Points High hydrostatic pressure

Complex 3D biofilm structure comprising cells in different physiological states distributed in different layers

Millijoule

Multiplicity of infection

Megapascal

Biofilm community that is formed by multiple bacterial species

Pathogens that cause infections and take advantage of an opportunity that is not normally available

Cells that survive a stress, e.g., antibiotic treatment, due to their lack of metabolism, staying in a resting state

Quaternary ammonium compounds

Cell-cell communication mechanism that synchronizes gene expression in response to the cell density of a given population

Ready to eat

Agent used to reduce the microbiological contamination to acceptable levels. These levels must conform the levels set by health regulations

Chemical action derived from the binding of a metal ion in solution with the formation of a soluble and stable complex

\section{References}

Abedon ST (2015) Ecology of anti-biofilm agents I: antibiotics versus bacteriophages. Pharmaceuticals (Basel) 8(3):525-558

Abedon ST (2016) Bacteriophage exploitation of bacterial biofilms: phage preference for less mature targets? FEMS Microbiol Lett 363:fnv246. https://doi.org/10.1093/femsle/fnv246. Epub 6 Jan 2016

Abedon ST (2017) Phage "delay" towards enhancing bacterial escape from biofilms: a more comprehensive way of viewing resistance to bacteriophages. AIMS Microbiol 3(2):186-226. https://doi.org/10.3934/microbiol.2017.2.186 
Abedon ST (2018a) Use of phage therapy to treat long-standing, persistent, or chronic bacterial infection. Adv Drug Deliv Rev. In press, pp 1-38

Abedon ST (2018b) Bacteriophage-mediated biocontrol of wound infections, and ecological exploitation of biofilms by phages. In: Recent Clinical Techniques, Results, and Research in Wounds. Springer, Cham

Annous BA, Smith JL, Fratamico PM (2009) Biofilms in fresh fruit and vegetables. In: Fratamico PM, Annous BA, Gunther NW (eds) Biofilms in the food and beverage industries. CRC Press, Boca Raton, pp 517-535

Arachchi GJ, Cridge AG, Dias-Wanigasekera BM et al (2013) Effectiveness of phages in the decontamination of Listeria monocytogenes adhered to clean stainless steel, stainless steel coated with fish protein, and as a biofilm. J Ind Microbiol Biotechnol 40:1105-1116

Arnold JW (2009) Biofilms in poultry processing. In: Fratamico PM, Annous BA, Gunther NW (eds) Biofilms in the food and beverage industries. Woodhead Publishing, Cambridge, UK, pp 455-473

Atterbury RJ, Connerton PL, Christine ER et al (2003) Application of host-specific bacteriophages to the surface of chicken skin leads to a reduction in recovery of Campylobacter jejuni. Appl Environ Microbiol 69:6302-6306

Azeredo J, Sutherland IW (2008) The use of phages for the removal of infectious biofilms. Curr Pharm Biotechnol 9:261-266

Beuchat LR (2002) Ecological factors influencing survival and growth of human pathogens on raw fruits and vegetables. Microbes Infect 4:413-423

Bhattacharjee AS, Choi J, Motlagh AM et al (2015) Bacteriophage therapy for membrane biofouling in membrane bioreactors and antibiotic-resistant bacterial biofilms. Biotechnol Bioeng 112:1644-1654

Bjarnsholt T, Buhlin K, Dufrêne YF, Gomelsky M, Moroni A, Ramstedt M, Rumbaugh KP, Schulte T, Sun L, Åkerlund B, Römling U (2018) Biofilm formation - what we can learn from recent developments. J Int Med. https://doi.org/10.1111/joim.12782. Epub ahead of print

Boyacioglu O, Sharma M, Sulakvelidze A, Goktepe I (2013) Biocontrol of Escherichia coli O157: $H 7$ on fresh-cut leafy greens. Bacteriophage 1:1-7

Bremer B, Seale B (2009) Biofilms in dairy processing. In: Fratamico PM, Annous BA, Gunther NW (eds) Biofilms in the food and beverage industries. CRC Press, Boca Raton, pp 396-431

Campagna C, Villion M, Labrie SJ et al (2014) Inactivation of dairy bacteriophages by commercial sanitizers and disinfectants. Int J Food Microbiol 171:41-47

Carlton RM, Noordman WH, Biswas B et al (2005) Bacteriophage P100 for control of Listeria monocytogenes in foods: genome sequence, bioinformatic analyses, oral toxicity study, and application. Regul Toxicol Pharmacol 43:301-312

Carter CD, Parks A, Abuladze T et al (2012) Bacteriophage cocktail significantly reduces Escherichia coli O157: H7 contamination of lettuce and beef, but does not protect against recontamination. Bacteriophage 2:178-185

Centers for Disease Control and Prevention (2006) Ongoing multistate outbreak of Escherichia coli serotype O157:H7 infections associated with consumption of fresh spinach, United States, September 2006. MMWR Morb Mortal Wkly Rep 55:1045-1046

Centers for Disease Control and Prevention (2011) CDC estimates of foodborne illness in the United States. https://www.cdc.gov/foodborneburden/2011-foodborne-estimates.html

Centers for Disease Control and Prevention (2016) Surveillance for foodborne disease outbreaks United States, 2014: Annual report, Atlanta

Ceri H, Olson ME, Stremick C, Read RR, Morck D, Buret A (1999) The Calgary biofilm device: new technology for rapid determination of antibiotic susceptibilities of bacterial biofilms. J Clin Microbiol 37:1771-1776

Chaudhry WN, Concepción-Acevedo J, Park T, Andleeb S, Bull JJ, Levin BR (2017) Synergy and order effects of antibiotics and phages in killing Pseudomonas aeruginosa biofilms. PLoS One 12:e168615. https://doi.org/10.1371/journal.pone.0168615 
Chawla R, Patil GR, Singh AK (2011) High hydrostatic pressure technology in dairy processing: a review. J Food Sci Technol 48:260-268

Chibeu A, Agius L, Gao A et al (2013) Efficacy of bacteriophage LISTEX ${ }^{\text {TMP } 100 ~ c o m b i n e d ~ w i t h ~}$ chemical antimicrobials in reducing Listeria monocytogenes in cooked Turkey and roast beef. Int J Food Microbiol 167:208-214

Chmielewski RAN, Frank JF (2003) Biofilm formation and control in food processing facilities. Compr Rev Food Sci Food Saf 2:22-32

Corcoran M, Morris D, De Lappe N et al (2014) Commonly used disinfectants fail to eradicate Salmonella enterica biofilms from food contact surface materials. Appl Environ Microbiol 80:1507-1514

Coughlan LM, Cotter PD, Hill C, Alvarez-Ordóñez A (2016) New weapons to fight old enemies: novel strategies for the (bio)control of bacterial biofilms in the food industry. Front Microbiol $7: 1-21$

De Oliveira DCV, Fernandes Júnior A, Kaneno R et al (2014) Ability of Salmonella spp. to produce biofilm is dependent on temperature and surface material. Foodborne Pathog Dis 11:1-6

Delaquis P, Bach S (2012) Resistance and sublethal damage. In: Gomez-Lopez VM (ed) Decontamination of fresh and minimally processed produce. Wiley-Blackwell, Oxford, pp 77-86

Dourou D, Beauchamp CS, Yoon Y et al (2011) Attachment and biofilm formation by Escherichia coli $\mathrm{O} 157: \mathrm{H7}$ at different temperatures, on various food-contact surfaces encountered in beef processing. Int J Food Microbiol 149:262-268

Dunne WM (2002) Bacterial adhesion: seen any good biofilms lately? Clin Microbiol Rev 15:155-166

European Food Safety Authority (2015) The European Union summary report on trends and sources of zoonoses, zoonotic agents and food-borne outbreaks in 2014. EFSA J 13:1-190

European Food Safety Authority (2016) The European Union summary report on trends and sources of zoonoses, zoonotic agents and food-borne outbreaks in 2015. EFSA J 14:1-231

Fairhead H (2009) SASP gene delivery: a novel antibacterial approach. Drug News Perspect 2009 (22):197-203. https://doi.org/10.1358/dnp.2009.22.4.1367708

Fish R, Kutter E, Wheat G, Blasdel B, Kutateladze M, Kuhl S (2016) Bacteriophage treatment of intransigent diabetic toe ulcers: a case series. J Wound Care 25(Suppl 7):S27-S33. https://doi. org/10.12968/jowc.2016.25.7.S27

Fish R, Kutter E, Wheat G, Blasdel B, Kutateladze M, Kuhl S (2018) Bacteriophage therapy for foot ulcer treatment as an effective step for moving toward clinical trials. Methods Mol Biol 1693:159-170. https://doi.org/10.1007/978-1-4939-7395-8_14

Flemming H-C, Wingender J, Szewzyk U et al (2016) Biofilms: an emergent form of bacterial life. Nat Rev Microbiol 14:563-575

Giaouris E, Heir E, Hébraud M et al (2014) Attachment and biofilm formation by foodborne bacteria in meat processing environments: causes, implications, role of bacterial interactions and control by alternative novel methods. Meat Sci 97:289-309

Gibbons I, Adesiyun A, Seepersadsingh N, Rahaman S (2006) Investigation for possible source (s) of contamination of ready-to-eat meat products with Listeria spp. and other pathogens in a meat processing plant in Trinidad. Food Microbiol 23:359-366

Goode D, Allen VM, Barrow PA (2003) Reduction of experimental Salmonella and campylobacter contamination of chicken skin by application of lytic bacteriophages. Appl Environ Microbiol 69(8):5032-5036

Gopal N, Hill C, Ross PR et al (2015) The prevalence and control of Bacillus and related sporeforming Bacteria in the dairy industry. Front Microbiol 6:1-18

Guenther S, Loessner MJ (2011) Bacteriophage biocontrol of Listeria monocytogenes on soft ripened white mold and red-smear cheeses. Bacteriophage 1:94-100

Guenther S, Huwyler D, Richard S, Loessner MJ (2009) Virulent bacteriophage for efficient biocontrol of Listeria monocytogenes in ready-to-eat foods. Appl Environ Microbiol 75:93-100 
Guenther S, Herzig O, Fieseler L et al (2012) Biocontrol of Salmonella typhimurium in RTE foods with the virulent bacteriophage FO1-E2. Int J Food Microbiol 154:66-72

Guglielmotti DM, Mercanti DJ, Reinheimer JA, Del Luján eQuiberoni A (2012) Review: efficiency of physical and chemical treatments on the inactivation of dairy bacteriophages. Front Microbiol 2:1-11

Guobjörnsdóttir B, Einarsson H, Thorkelsson G (2005) Microbial adhesion to processing lines for fish fillets and cooked shrimp: influence of stainless steel surface finish and presence of gramnegative bacteria on the attachment of Listeria monocytogenes. Food Technol Biotechnol 43:55-61

Gutiérrez D, Rodríguez-Rubio L, Martínez B et al (2016) Bacteriophages as weapons against bacterial biofilms in the food industry. Front Microbiol 7:1-15

Haldar SC (2012) Vibrio related diseases in aquaculture and development of rapid and accurate identification methods. J Mar Sci Res Dev S1:1-7

Han H, Wei X, Wei Y et al (2017) Isolation, characterization, and Bioinformatic analyses of lytic Salmonella Enteritidis phages and tests of their antibacterial activity in food. Curr Microbiol 74:1-9

Harper DR, Parracho HMRT, Walker J, Sharp R, Hughes G, Werthén M, Lehman S, Morales S (2014) Bacteriophages and biofilms. Antibiotics 3:270-284. https://doi.org/10.3390/ antibiotics 3030270

Harper DR (2018) Criteria for Selecting Suitable Infectious Diseases for Phage Therapy. Viruses 10(4). pii: E177. https://doi.org/10.3390/v10040177

Hawkins C, Harper DR, Burch D, Anggard E, Soothill J (2010) Topical treatment of Pseudomonas aeruginosa otitis of dogs with a bacteriophage mixture: a before/after clinical trial. Vet Microbiol 146:309-313. https://doi.org/10.1016/j.vetmic.2010.05.014

Hayes S, Murphy J, Mahony J et al (2017) Biocidal inactivation of Lactococcus lactis bacteriophages: efficacy and targets of commonly used sanitizers. Front Microbiol 8:1-14

Hite BH (1899) The effect of pressure in the preservation of milk: a preliminary report. West Virginia Agricultural Experiment Station, Morgantown

Hong Y, Pan Y, Ebner PD (2014) Meat science and muscle biology symposium: development of bacteriophage treatments to reduce Escherichia coli $\mathrm{O} 157: \mathrm{H} 7$ contamination of beef products and produce. J Anim Sci 92:1366-1377

Hooton SPT, Atterbury RJ, Connerton IF (2011) Application of a bacteriophage cocktail to reduce Salmonella typhimurium U288 contamination on pig skin. Int J Food Microbiol 151:157-163

Iacumin L, Manzano M, Comi G (2016) Phage inactivation of Listeria monocytogenes on san Daniele dry-cured ham and elimination of biofilms from equipment and working environments. Microorganisms 4:1-12

Jahid IK, Ha S-D (2014) Inactivation kinetics of various chemical disinfectants on Aeromonas hydrophila planktonic cells and biofilms. Foodborne Pathog Dis 11:346-353

Jindal S, Anand S, Huang K et al (2016) Evaluation of modified stainless steel surfaces targeted to reduce biofilm formation by common milk sporeformers. J Dairy Sci 99:9502-9513

Joseph B, Otta SK, Karunasagar I, Karunasagar I (2001) Biofilm formation by Salmonella spp. on food contact surfaces and their sensitivity to sanitizers. Int J Food Microbiol 64:367-372

Kang HW, Kim JW, Jung TS, Woo GJ (2013) wksl3, a new biocontrol agent for Salmonella enterica serovars Enteritidis and typhimurium in foods: characterization, application, sequence analysis, and oral acute toxicity study. Appl Environ Microbiol 79:1956-1968

Kingsley D (2014) High pressure processing of bivalve shellfish and HPP's use as a virus intervention. Foods 3:336-350

Kingsley DH, Holliman DR, Calci KR et al (2007) Inactivation of a norovirus by high-pressure processing. Appl Environ Microbiol 73:581-585

Korber DR, Mangalappalli-Illathu AK, Vidović S (2009) Biofilm formation by food spoilage microorganisms in food processing environments. In: Fratamico PM, Annous BA, Gunther NW (eds) Biofilms in the food and beverage industries. CRC Press, Boca Raton, pp 169-199 
Kowitt B (2016) Why our food keeps making us sick. In: Fortune. http://fortune.com/foodcontamination/. Accessed $20 \mathrm{Feb} 2018$

Kujiraoka M, Kuroda M, Asai K et al (2017) Comprehensive diagnosis of bacterial infection associated with acute cholecystitis using metagenomic approach. Front Microbiol 8:1-7

Kumar CG, Anand S (1998) Significance of microbial biofilms in food industry: a review. Int J Food Microbiol 42:9-27

Kumaran D, Taha M, Yi Q, Ramirez-Arcos S, Diallo JS, Carli A, Abdelbary H (2018) Does treatment order matter? Investigating the ability of bacteriophage to augment antibiotic activity against Staphylococcus aureus biofilms. Front Microbiol 9:127. https://doi.org/10.3389/ fmicb.2018.00127

Latorre AA, Van Kessel JS, Karns JS et al (2010) Biofilm in milking equipment on a dairy farm as a potential source of bulk tank milk contamination with Listeria monocytogenes. J Dairy Sci 93:2792-2802

Lee H, Ku H-JJ, Lee D-HH et al (2016) Characterization and genomic study of the novel bacteriophage HY01 infecting both Escherichia coli O157:H7 and Shigella flexneri: potential as a biocontrol agent in food. PLoS One 11:1-21

Lequette Y, Boels G, Clarisse M, Faille C (2010) Using enzymes to remove biofilms of bacterial isolates sampled in the food-industry. Biofouling 26:421-431

Leverentz B, Conway W, Alavidze Z et al (2001) Examination of bacteriophage as a biocontrol method for Salmonella on fresh-cut fruit: a model study. J Food Prot 64:1116-1121

Leverentz B, Conway WS, Camp MJ et al (2003) Biocontrol of Listeria monocytogenes on freshcut produce by treatment with lytic bacteriophages and a bacteriocin. Society 69:4519-4526

Lewis K (2010) Persister Cells. Annu Rev Microbiol 64:357-372

Liu NT, Lefcourt AM, Nou X et al (2013) Native microflora in fresh-cut produce processing plants and their potentials for biofilm formation. J Food Prot 76:827-832

Liu H, Niu YD, Meng R et al (2015) Control of Escherichia coli $\mathrm{O} 157$ on beef at 37, 22 and $4^{\circ} \mathrm{C}$ by T5-, T1-, T4-and O1-like bacteriophages. Food Microbiol 51:69-73

Lu TK, Collins JJ (2007) Dispersing biofilms with engineered enzymatic bacteriophage. Proc Natl Acad Sci 27:11197-11202

Ly-Chatain MH (2014) The factors affecting effectiveness of treatment in phages therapy. Front Microbiol 5:1-7

Lynch MF, Tauxe RV, Hedberg CW (2009) The growing burden of foodborne outbreaks due to contaminated fresh produce: risks and opportunities. Epidemiol Infect 137:307-315

Mah TF, Pitts B, Pellock B, Walker GC, Stewart PS, O'Toole GA (2003) A genetic basis for Pseudomonas aeruginosa biofilm antibiotic resistance. Nature 426:306-310

Marin C, Hernandiz A, Lainez M (2009) Biofilm development capacity of Salmonella strains isolated in poultry risk factors and their resistance against disinfectants. Poult Sci 88:424-431

Mercanti DJ, Guglielmotti DM, Patrignani F et al (2012) Resistance of two temperate Lactobacillus paracasei bacteriophages to high pressure homogenization, thermal treatments and chemical biocides of industrial application. Food Microbiol 29:99-104

Mizan MFR, Jahid IK, Ha S-D (2015) Microbial biofilms in seafood: a food-hygiene challenge. Food Microbiol 49:41-55

Mizan MFR, Jahid IK, Kim M et al (2016) Variability in biofilm formation correlates with hydrophobicity and quorum sensing among Vibrio parahaemolyticus isolates from food contact surfaces and the distribution of the genes involved in biofilm formation. Biofouling 32:497-509

Møretrø T, Schirmer BCT, Heir E et al (2017) Tolerance to quaternary ammonium compound disinfectants may enhance growth of Listeria monocytogenes in the food industry. Int J Food Microbiol 241:215-224

Morgan IR, Krautil FL, Craven JA (1987) Effect of time in lairage on caecal and carcass Salmonella contamination of slaughter pigs. Epidemiol Infect 98:323-330

Mustapha S, Mustapha EM, Nozha C (2013) Vibrio alginolyticus : an emerging pathogen of foodborne diseases. Int J Sci Technol 2:302-309 
National Research Council (US) Subcommittee on Microbiological Criteria (1985) An evaluation of the role of microbiological criteria for foods and food ingredients. National Academy Press, Washington, DC

Oliver SP, Jayarao BM, Almeida RA (2005) Foodborne pathogens in Milk and the dairy farm environment: food safety and public health implications. Foodborne Pathog Dis 2:115-129

Pan Y, Breidt F, Kathariou S (2006) Resistance of Listeria monocytogenes biofilms to sanitizing agents in a simulated food processing environment. Appl Environ Microbiol 72:7711-7717

Patel J, Sharma M, Millner P et al (2011) Inactivation of Escherichia coli O157:H7 attached to spinach harvester blade using bacteriophage. Foodborne Pathog Dis 8:541-546

Pearl S, Gabay C, Kishony R, Oppenheim A, Balaban NQ (2008) Nongenetic individuality in the host-phage interaction. PLoS Biol 6:e120

Pereira A, Melo LF (2009) Monitoring of biofilms in the food and beverage industries. In: Fratamico PM, Annous BA, Gunther NW (eds) Biofilms in the food and beverage industries. CRC Press, Boca Raton, pp 131-151

Perera MN, Abuladze T, Li M et al (2015) Bacteriophage cocktail significantly reduces or eliminates Listeria monocytogenes contamination on lettuce, apples, cheese, smoked salmon and frozen foods. Food Microbiol 52:42-48

Phagoburn (2018). Available online: http://www.phagoburn.eu (accessed on 11 Sept 2018)

Prakash B, Veeregowda BM, Krishnappa G (2003) Biofilms: a survival strategy of bacteria. Curr Sci 85:1299-1307

Raffaella C, Casettari L, Fagioli L et al (2017) Activity of essential oil-based microemulsions against Staphylococcus aureus biofilms developed on stainless steel surface in different culture media and growth conditions. Int J Food Microbiol 241:132-140

Rhoads DD, Wolcott RD, Kuskowski MA, Wolcott BM, Ward LS, Sulakvelidze A (2009) Bacteriophage therapy of venous leg ulcers in humans: results of a phase I safety trial. J Wound Care 18(6):237-238. https://doi.org/10.12968/jowc.2009.18.6.42801

Richter FL, Cords BR (2001) Formulation of sanitizers and disinfectants. In: Block SS (ed) Disinfection, sterilization, and preservation. Lippincott Williams \& Wilkins, Philadelphia, pp 473-490

Rose T, Verbeken G, Vos DD, Merabishvili M, Vaneechoutte M, Lavigne R, Jennes S, Zizi M, Pirnay JP (2014) Experimental phage therapy of burn wound infection: difficult first steps. Int J Burns Trauma 4:66-73

Roy B, Ackermann HW, Pandian S et al (1993) Biological inactivation of adhering Listeria monocytogenes by listeriaphages and a quaternary ammonium compound. Appl Environ Microbiol 59:2914-2917

Ruppé E, Lazarevic V, Girard M et al (2017) Clinical metagenomics of bone and joint infections: a proof of concept study. Sci Rep 7:7718

Sampathkumar B, Khachatourians G, Korber D (2005) Food processing biofilms and antimicrobial agents. In: Hui YH (ed) Handbook of food science, technology, and engineering. Taylor \& Francis, Boca Raton, pp 84-81

Sasikala D, Srinivasan P (2016) Characterization of potential lytic bacteriophage against Vibrio alginolyticus and its therapeutic implications on biofilm dispersal. Microb Pathog 101:24-35

Shikongo-Nambabi MNNN, Kachigunda B, Venter SN (2010) Evaluation of oxidising disinfectants to control vibrio biofilms in treated seawater used for fish processing. Water SA 36:215-220

Shin G-A, Linden KG, Sobsey MD (2005) Low pressure ultraviolet inactivation of pathogenic enteric viruses and bacteriophages. Journal of Environmental Engineering and Science 4(S1): S7-S11

Silagyi K, Kim S-H, Martin Lo Y, Wei C (2009) Production of biofilm and quorum sensing by Escherichia coli $\mathrm{O} 157: \mathrm{H} 7$ and its transfer from contact surfaces to meat, poultry, ready-to-eat deli, and produce products. Food Microbiol 26:514-519

Sillankorva S, Azeredo J (2014) The use of bacteriophages and bacteriophage-derived enzymes for clinically relevant biofilm control. In: Borysowski J, Miedzybrodzki R, Gorski A (eds) Phage therapy: current research and applications. Caister Academic Press, Norfolk 
Sillankorva S, Oliveira R, Vieira MJ et al (2004) Bacteriophage phi S1 infection of Pseudomonas fluorescens planktonic cells versus biofilms. Biofouling 20:133-138

Sillankorva S, Neubauer P, Azeredo J (2008) Pseudomonas fluorescens biofilms subjected to phage phiIBB-PF7A. BMC Biotechnol 8:1-12

Sillankorva S, Neubauer P, Azeredo J (2010) Phage control of dual species biofilms of Pseudomonas fluorescens and Staphylococcus lentus. Biofouling 26:567-575

Sillankorva S, Neubauer P, Azaredo J (2011) Use of bacteriophages to control biofilms. LAP Lambert Academic Publishing, Saarbrücken

Silva ENG, Figueiredo ACL, Miranda FA, de Castro Almeida RC (2014) Control of Listeria monocytogenes growth in soft cheeses by bacteriophage P100. Brazilian J Microbiol 45:11-16

Simões M, Simões LC, Vieira MJ (2010) A review of current and emergent biofilm control strategies. LWT-Food Sci Technol 43:573-583

Snyder AB, Perry JJ, Yousef AE (2016) Developing and optimizing bacteriophage treatment to control enterohemorrhagic Escherichia coli on fresh produce. Int J Food Microbiol 236:90-97

Spoering AL, Lewis K (2001) Biofilms and planktonic cells of Pseudomonas aeruginosa have similar resistance to killing by antimicrobials. J Bacteriol 183:6746-6751

Spricigo DA, Bardina C, Cortés P et al (2013) Use of a bacteriophage cocktail to control Salmonella in food and the food industry. Int J Food Microbiol 165:169-174

Srey S, Jahid IK, Ha S-D (2013) Biofilm formation in food industries: a food safety concern. Food Control 31:572-585

Srivastava S, Bhargava A (2016) Biofilms and human health. Biotechnol Lett 38:1-22

Stanfield P (2003) Cleaning and sanitizing a food plant. In: Hui YH, Bruinsma BL, Gorham JR et al (eds) Food plant sanitation. Marcel Dekker, Inc., New York, pp 101-115

Sukumaran AT, Nannapaneni R, Kiess A, Sharma CS (2015) Reduction of Salmonella on chicken meat and chicken skin by combined or sequential application of lytic bacteriophage with chemical antimicrobials. Int J Food Microbiol 207:8-15

Tait K, Skillman LC, Sutherland IW (2002) The efficacy of bacteriophage as a method of biofilm eradication. Biofouling 18:305-311. https://doi.org/10.1080/0892701021000034418

Teh AHT, Lee SM, Dykes GA (2014) Does Campylobacter jejuni form biofilms in food-related environments? Appl Environ Microbiol 80:5154-5160

Uchiyama J, Shigehisa R, Nasukawa T, Mizukami K, Takemura-Uchiyama I, Ujihara T, Murakami H, Imanishi I, Nishifuji K, Sakaguchi M, Matsuzaki S (2018) Piperacillin and ceftazidime produce the strongest synergistic phage-antibiotic effect in Pseudomonas aeruginosa. Arch Virol 163:1941-1948. https://doi.org/10.1007/s00705-018-3811-0

Van Houdt R, Michiels CW (2010) Biofilm formation and the food industry, a focus on the bacterial outer surface. J Appl Microbiol 109:1117-1131

Vestby LK, Møretrø T, Langsrud S et al (2009) Biofilm forming abilities of Salmonella are correlated with persistence in fish meal- and feed factories. BMC Vet Res 5:1-6

Viazis S, Akhtar M, Feirtag J, Diez-Gonzalez F (2011) Reduction of Escherichia coli O157:H7 viability on hard surfaces by treatment with a bacteriophage mixture. Int J Food Microbiol $145: 37-42$

Wang J, Ray AJ, Hammons SR, Oliver HF (2015) Persistent and transient Listeria monocytogenes strains from retail deli environments vary in their ability to adhere and form biofilms and rarely have inlA premature stop codons. Foodborne Pathog Dis 12:151-158

Winkelströter LK, dos Reis Teixeira FB, Silva EP et al (2014) Unraveling microbial biofilms of importance for food microbiology. Microb Ecol 68:35-46

Wood TK, Knabel SJ, Kwan BW (2013) Bacterial persister cell formation and dormancy. Appl Environ Microbiol 79:7116-7121

Woolston J, Parks AR, Abuladze T et al (2013) Bacteriophages lytic for Salmonella rapidly reduce Salmonella contamination on glass and stainless steel surfaces. Bacteriophage 3:1-6

Wright A, Hawkins C, Anggard EA, Harper DR (2009) A controlled clinical trial of a therapeutic bacteriophage preparation in chronic otitis due to antibiotic-resistant Pseudomonas aeruginosa; 
a preliminary report of efficacy. Clin Otolaryngol 34(4):349-357. https://doi.org/10.1111/ j.1749-4486.2009.01973.x

You L, Suthers PF, Yin J (2002) Effects of Escherichia coli physiology on growth of phage T7 in vivo and in silico. J Bacteriol 184:1888-1894

Zhang Y, Hu Z (2013) Combined treatment of Pseudomonas aeruginosa biofilms with bacteriophages and chlorine. Biotechnol Bioeng 110:286-295

Zhang Y, Hunt HK, Hu Z (2013) Application of bacteriophages to selectively remove Pseudomonas aeruginosa in water and wastewater filtration systems. Water Res 47:4507-4518 